い出定ろそ的あ心こな稿

まてすしくのにるとうなメは本

ずのよな流意把のこ課わ力、章

、若うい通味握から題れ二現の

政干なまし内吊なでをで゙在主

策のもまて 容るこ負い允の題

策吟の記いがたの政わるをわは

と味で述る必め用策せか通が、

はかあをなずの語決らと策り国政

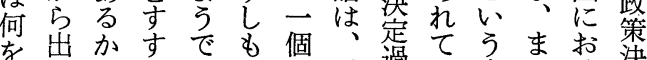

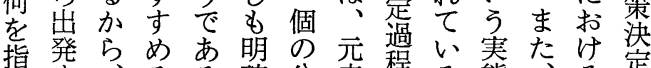

指势、るる。確分来程る態たけ定政

てるまこ。で析文とわ势ど各過策

序 I

らとさ、と今な用現は語多の種の

のに政、私まに政二あなお政概

かし策あの市治体るりり策観

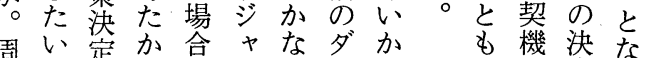

論

政

策

決

定

過

程

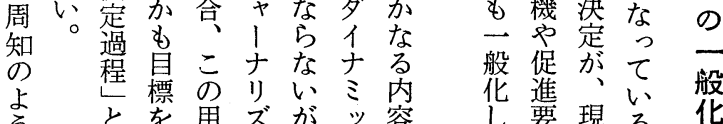

の

にと定用語がッ容允要現る 化

概

$\mathrm{D}$ 用ず意ど察を希整よどを

- 語に味にに機概 すつのり

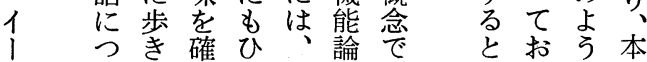

钼

今ンく動の政の語連抒い法を構 ス

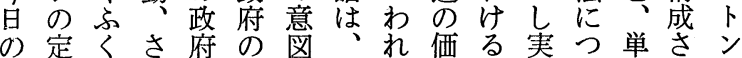

い義めらや社の単わ值さ施いに捻

わをてに各会みにれ判らのてている

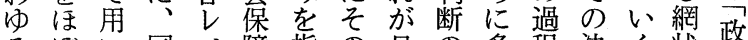

るぼ、同へ障指の旦の多程決く状策

妥ら法ル制す主常体く彼定つの著

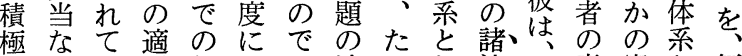

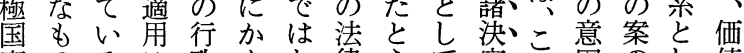

家のるに政んな律えて定れ図のし值

ᄂととか庁すく国ばとやをを中て配

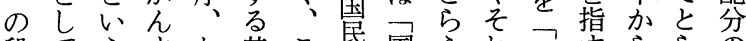

段てえすな基こ年国えれ政守ららの

階受るるい本の年のよら策に選えた にけか司し方法金年うに策と択てめ

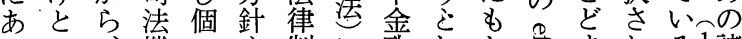

つ、機々や制に政しと禹まれる諸

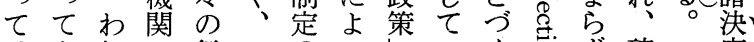

はよれの行このつしいく㐫ず確つ定

国でれ諸官政の基て とる礎表呼と活な局そ究まりと、

のあは定の律や現ふ心動面のれ、諸

ろこな諸の源さ場えを面意た彼活、

政 うののと決奉泉れ合るもと図価は動

策。

本し、ろ活めた国用 一にな方策て 
をにな方政おゆ一経系でれ家まなて てなね造み質 みもつら針策よる個済のはらので今おうのるれ出にを

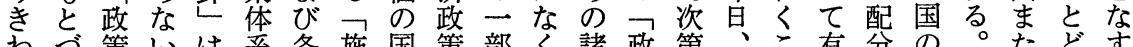
わう策、は采各施国策部々諸政第、国直分の。たどす

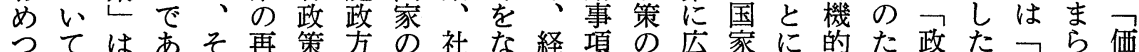
?妾まろ扎編体針政会し済に洪沉はしにめ策が生ず值 、案たう。臬成系策政て加に氷に構の立、の

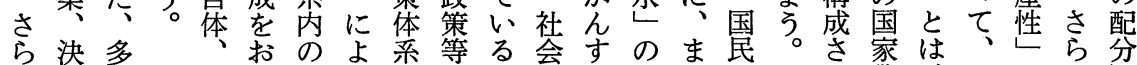

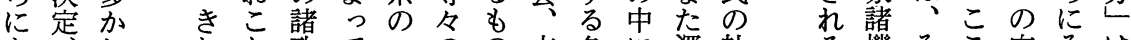
あ、れな政て二のの文各に深社る機そこ向そは ら実少めつ策、部各で教政日会 た施なてて間こ分価あ等策々関生 なさか高いにれで值る々はの与活 政れ机るアらあ領この、生す上 策なおクのる域と各そ活るの 加そ政 一けセ各がごは価れをよき 立の策箇でン価、とい值ぞ送うわ 案実ののあト值そのう領れうにめ 施被方の領の政ま域個てなて 決後適政。強域時策でこ別いり些 定の用策こ弱ご々体もと的る、細 被者它をとの系なの的をね 実適の と場与の政は、網孤いれ事 施角要見合文政府、。状立えわ項 さ者求なの策はそさの的るれに れのやけ口国体、れら政ながはい

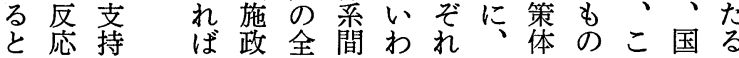
一関れで上の、 連のぞはを社単 の諸れ、多会に 価決のひふでそ 值定価とくのの 判と值まめ各社 断、領ずた種 会 のそ域わ意ので 体れにれ味社の 系らおわで 会 既 ををけれ理的存 指 るる 解 価 の すぐ価考 寸 值 価 もる 值 察 べの 值 の諸ののき積の と活 増 対 だ極 配 考 動 殖 象と的 分 えにと思なの

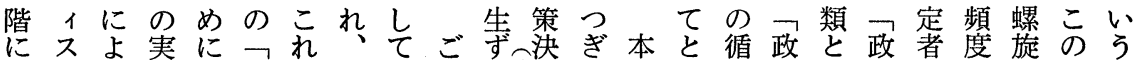

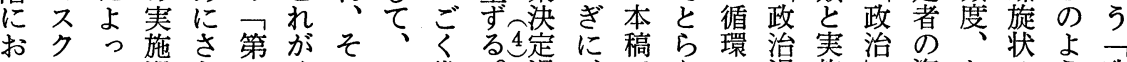

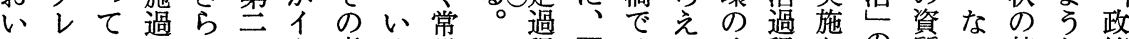
て シ 、程にの! 意く識程政はるるサ程を局質い航な策

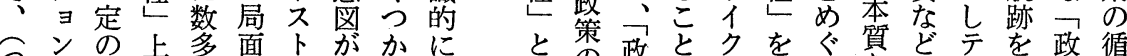

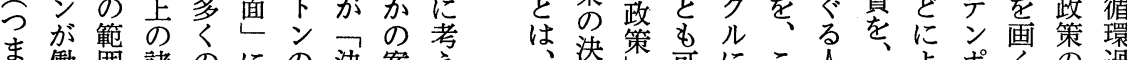

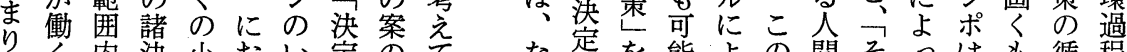

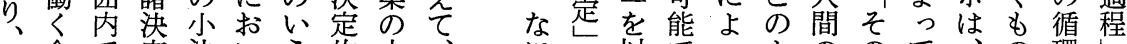

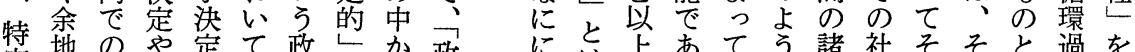

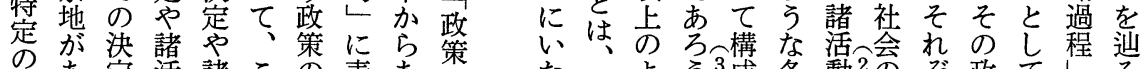

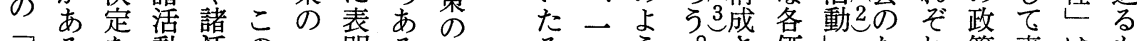

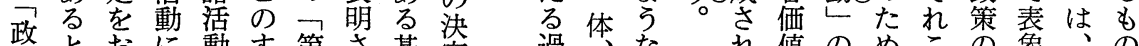
紫とおに動す第さ基定過体な值のめこの象、の 策いこ際がで卆本走程具意領中にと関さ時と

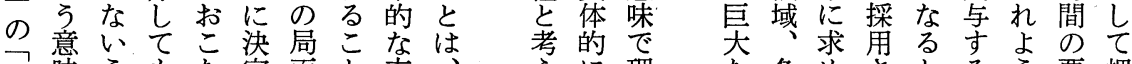

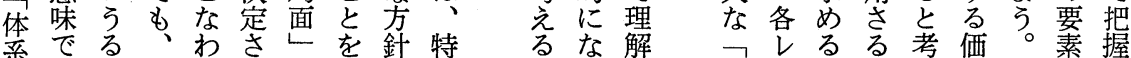

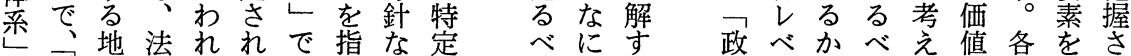
の政位律るたあすす価きをる策ルぎきねの種加れ 中策にそが意るとし值るか指こ循でり権ば種のえる で実あの、図。考意の としと環のに威な類政てべ の施る他このつえ図配 い、に無お的らや策考き

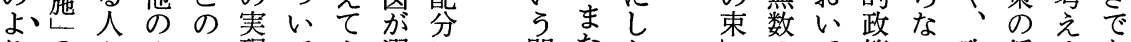
りの々ル現でよ選に問たた过たて策い政循るあ

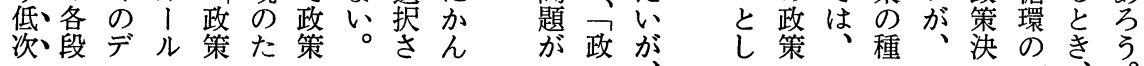




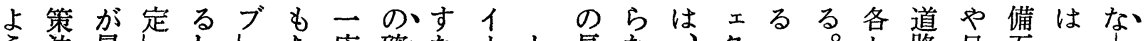

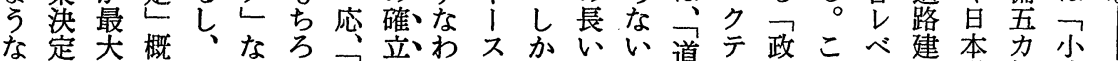

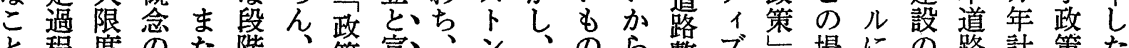

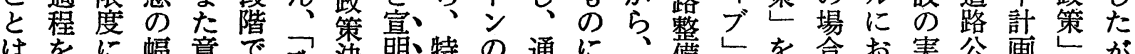

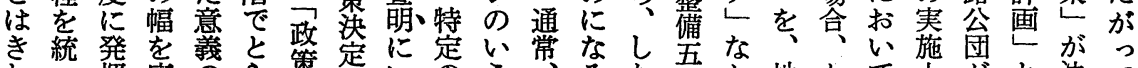

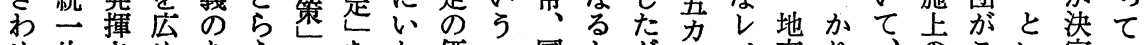

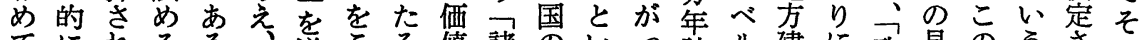

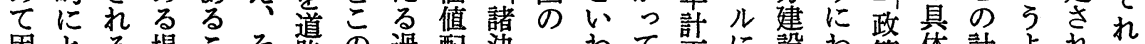

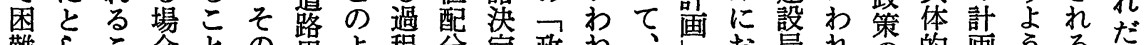

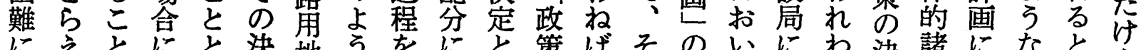

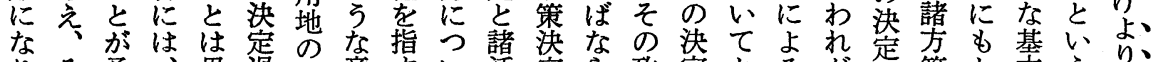
りそ予、思過買意守以活定ら政定とるが正策と本えり、

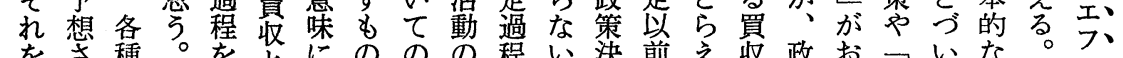
つをさ種。をとにののの程い決前え收政抏いいな。

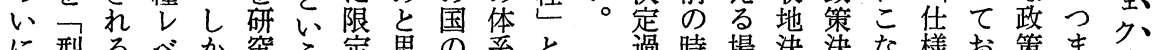

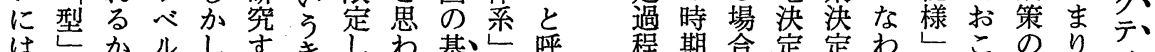

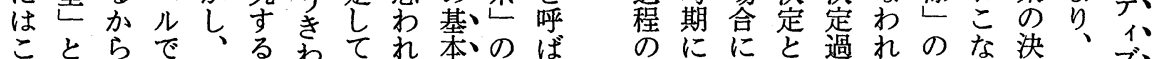

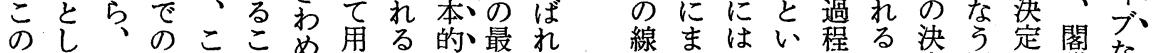

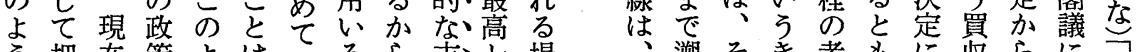

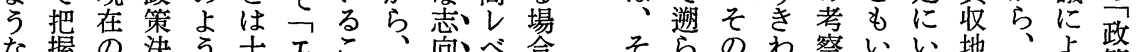

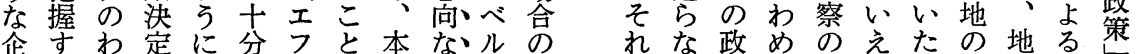
図るがの哥ェに稿いで多だけ策て対るる決方车 はと国特政能クしでしいのく汀れのへ象の定建道な 放いの異策でテたは意決は距ば锹エとででや設路い

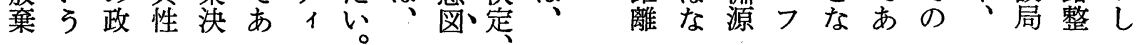

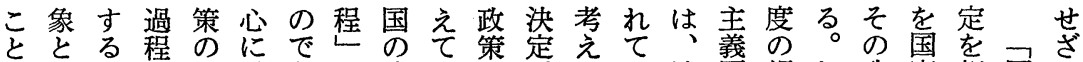

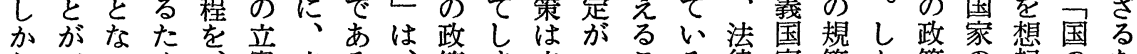

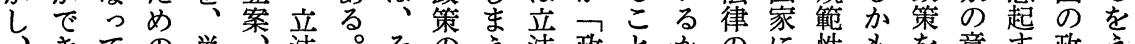
、ての単法。その芝政とかのに性もを意す政え 政るい努に作過最の決ば部治はら形打を、害思る策な 政加る力立成程近ま定等方多、式い保法現とこのく

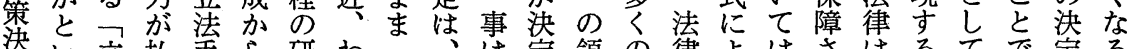
決心立払手ら研わ行は定領の律よはさはるてて定る 定了法わ続国究が立法いし域場のつ执、た採あ化 過疑過れに会の国法法た、合制て国て国め角ろとあ

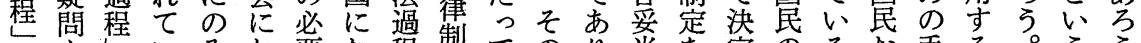

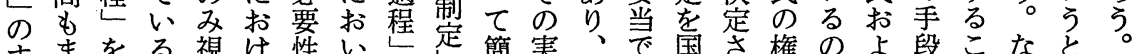

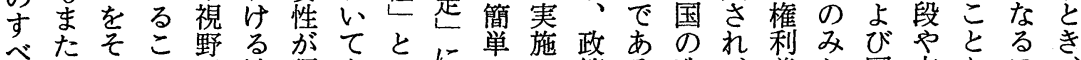
て生のと党法も心ににに策ろ政義な国方をほ

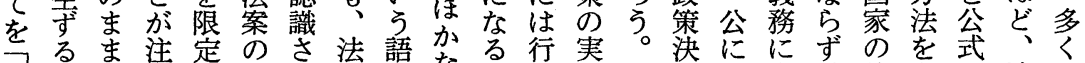
立の儿自す審れ律になら政施こ定明直、諸むに法の 法で政さる議る学置らす部がの尔尔す機明表律人

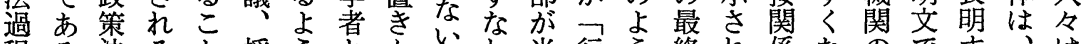

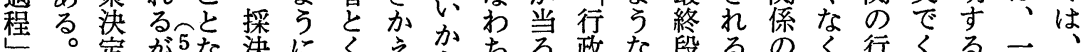

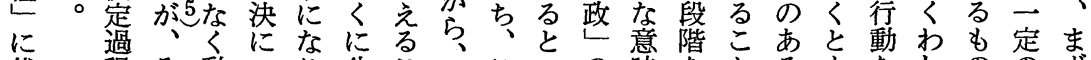
代程そ動いり公こうこいの味をとるも意ししののず 弁治 の態た、法と政のう段で示が重現規くで内

さと観的る各学が策場ふ階、す原要在制定あ容法 せ考察に

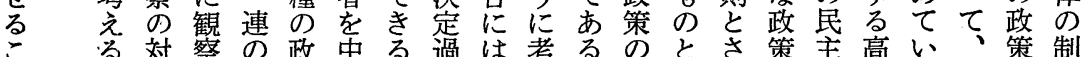




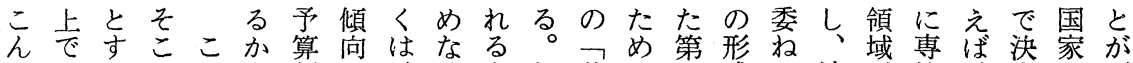
でのるにの額を、け毛し基の兰式る法加管定に不

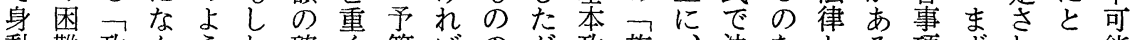
動難政んうれ確く算ばの代政施、決をとる項ずれっ能 きに策らにな定見的なほつ策政そ定避ししと第るてな

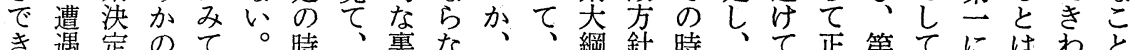

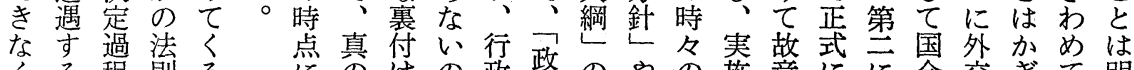
なる程唄る裘をで部策ごやの施意にに会交ぎて明 り汀なな味まあ内浞と数閣て閣定政はあな要加 そで般い各なでっるに定き多はい議等府か諸いなで

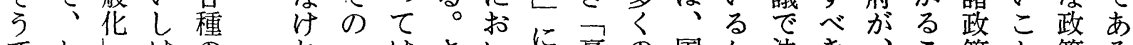

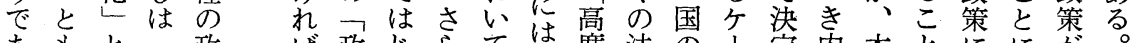
あもと型ば政じらて度法の!定内本とににが。 るすい型策な策めに完立の律政不し容来な代注、す れう決ら決て結法政や策もたのなく表意必な しば任と定奴定実現守法策政体きり重ら決さしすお 加不事い過と効在るの令系わ、要ば定执なし

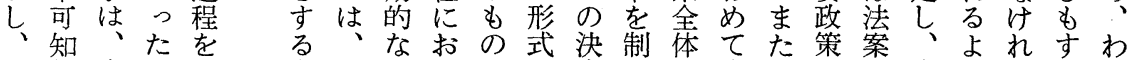
わ論まも統考そもけもに定定の多はをと䒠うばべれ れ的すの劣ののる数よを再い政国し施になてわ わな対を的方政に二多っおる編の令国てし人るれ れ迷象発にも策な政いてこ贯をで、会国て政ま法は は路を見と可にる策こ打な胎打あ通の会い府い律、

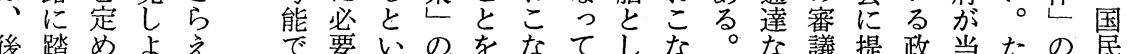

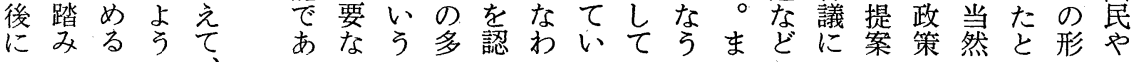

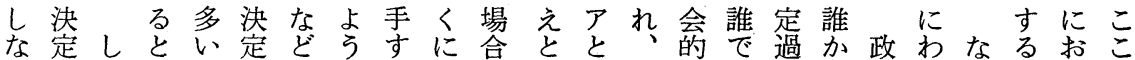

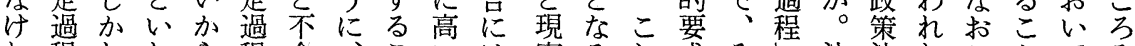

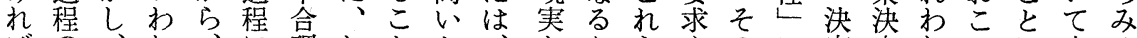
ばの、权、に理わとと、とからやに定定れのに完る な一こばわつながはいB方、の問影参主過をほよ結よ ら般のなが過要国きう・等情題響加体程待かっすう な化よる国程素のわへ $\mathrm{M}$ 致々報の力しはのちにてるに

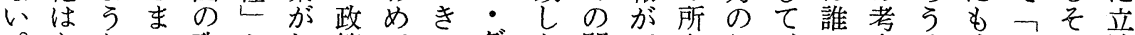
○あない政とし策てでグな問ど在行てで察け政迷れ法 一る幾。策呼ば決困あ航題のに使そ卡て策路と部

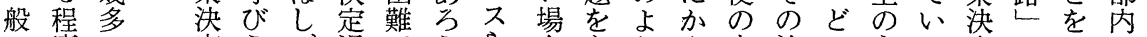
に度の定うば過でらら合あうん方決の主る定か一に

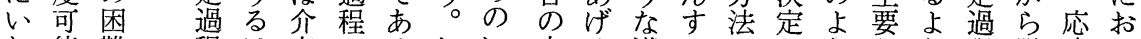
わ能難程ほ在にるしい方る導るはにうなう程脱分い れでが のどすは。少うがこ管情ど明な指での出離て

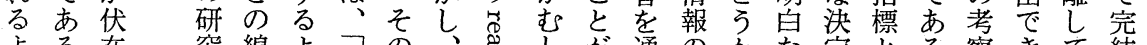

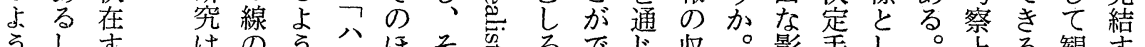

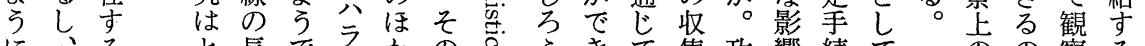
に、を長で巷かのぶきて集政響続て のの祭る

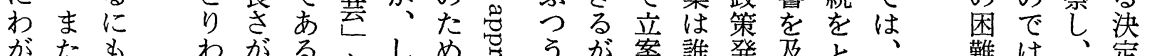

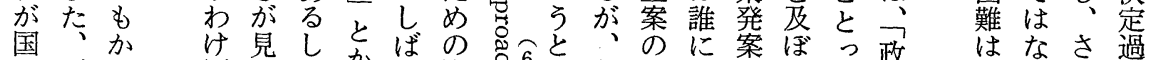

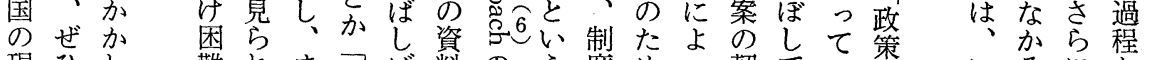

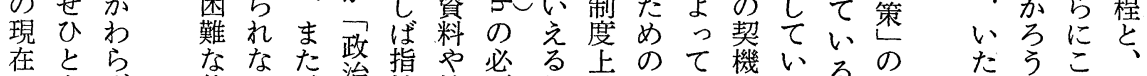

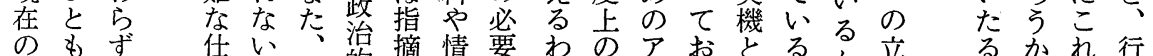

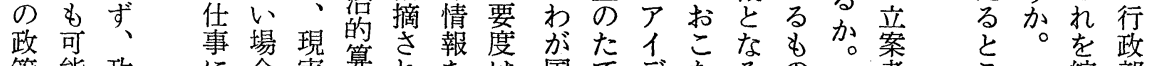

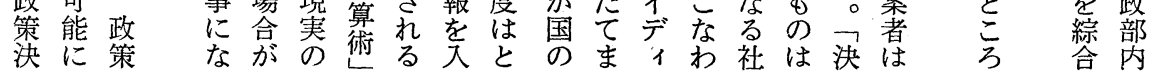




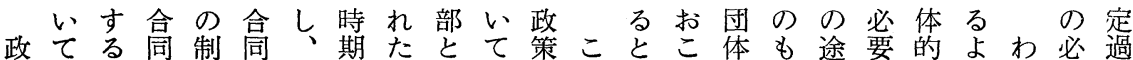
策もこ以限以政にとし検決の考ななと芯がなうれ要程 決若と後か後策お考て討定よえう占にひあ個なわ性に

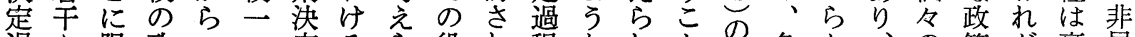
過尔限政い二定るら役れ程なれと体各か、の策が高民 程れ定策っ年過政れ割るへ意るは質種れそ政内㐫主 上るし のて間程策るをはの図。、筫のるれ策容のる的 のこ、決とに上決保果ず主の 政政政とらの別よと要 諸とさ定うおの定守守で要も策策治思の決のうい素 問にら機てけ各過合たあなと決企勢う研定類ならや 題しに構いる局程同める参に定画力。究過型7要心非 諸い政決可型での面卡時にそ者本薖能政さ成程に請き含 事。府定能のの主よ現こを特

項・過で変諸要び在で個集

に与程あ化問なその、別で

々 党上るの題差执政こ的は

てょ重らとを異後決章と次

はる要、をう概の定でり章 世な本たら観時過はあ以

従論特稿ど的し 期程、げ市 来操徴でるにてとの次、に 種作にはこ扱み、原章右お 々のう、といたそ型以のい の 現いもは、いれが市諸て 視況てっ、し形の点こ 角に検ぱ紙かし前成導にれ か つ討 ら 数も名のさ入つら の党にの実る応あ的 二行官门証各え万要 般動官政み的種るう。素 化倫僚策重なのた。势 に理自決水研政め多 とと治定の究8策にけ つ行体過上と決は、标 て動財䅅に定、篠多 わ式界とは行程原い めなそいじ的の- ほ

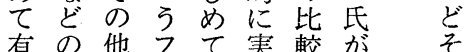
効解のレ理施と設の で明 利 I 論す掟 観 あを益么化る具守察

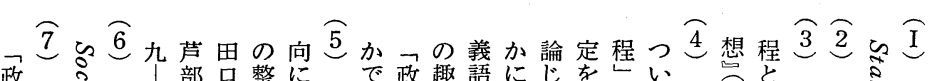

作 成 究 5

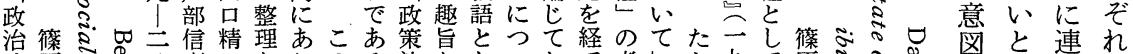

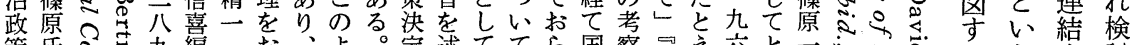

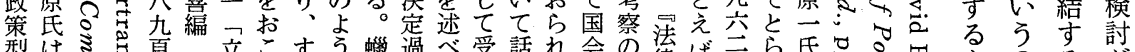

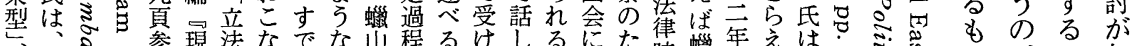

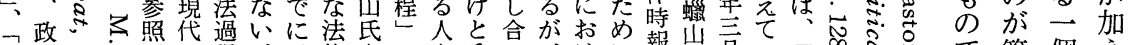

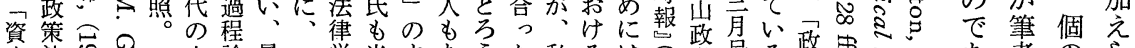

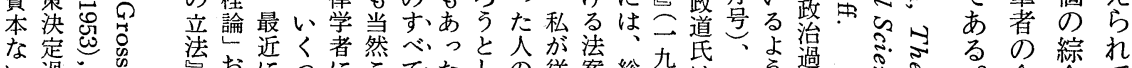

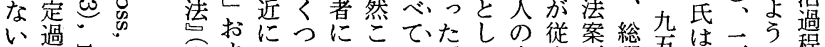

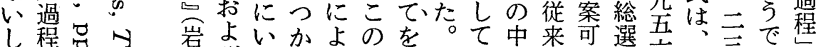

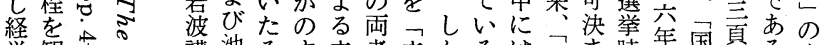
嫦観へ講池るす立者立加るは政ま時年国悬る内

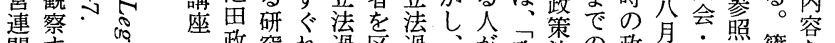

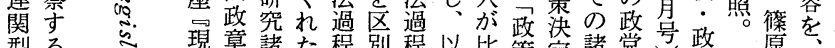
型る 階の る 法現果績研てと究考本多定程を階公四立政策 階の II 㴻星 V 争

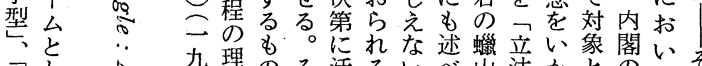

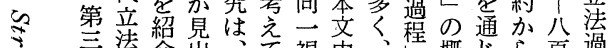

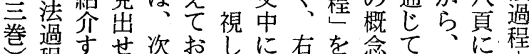
程るる第らえをに右を念て対内打

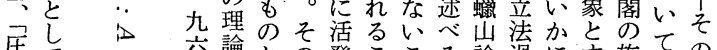
生仮 分論との発ここる論過にす寸施て、の

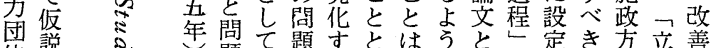
体説 年閶て題すとはらとし定き方立善 型に的点題意る思明に同と立だ針法策 治定 過過 程 程 の 類 螺 型 旋 华的 (上) 循 の. る の綜れ ○す念合て 灾芒筫角る

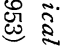
? ㄷํㅇ 峞密 あとこ。 る゙しこ の よ 本 $\neg 5$ 稿政な は策各 ミ定解 है. の 過 か た程ら め論す の る 畕過 集 彯硣 
題ててたてに配す政定ていいし 各体

周はのわと根置る政現機いいいて種系こ

の知治でに充的若政省在構るるるいる策指で

よ後形あ堡な辛治編政と個も主決卞心

うの態っ変の葧期策はのの要定もう

にわのて、党化変吕間で定政力考政程で政

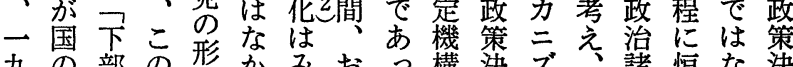

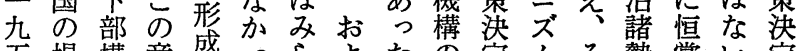

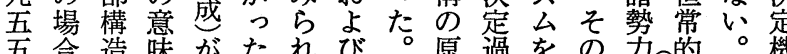

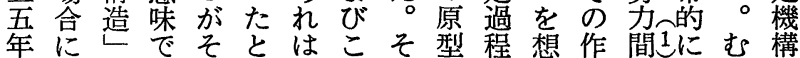

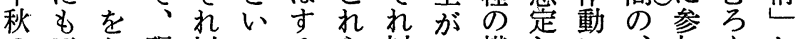
の正な現以っるら以形横しに、加んと

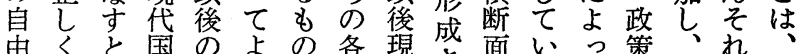
冑娈い家政いのの 構在さ面いるて策々れ れ 主当うに治。、成ま指の各定の無な 党す $M$ おのつ政要でた方で種上決狦る のる・い流ま策素、のもあの宁定係 政 結と デてれり決の政はのるっ権にで策 成い二はを、定内策、と政方明は決 はえヴ、決政機部決一考つ策配白な定

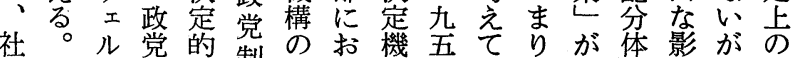

会湆制に制構け構五括方生系響法

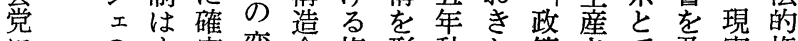
にのす定変全権形秋た策さ等字実権 対命べし動体力成の心決れ应の限

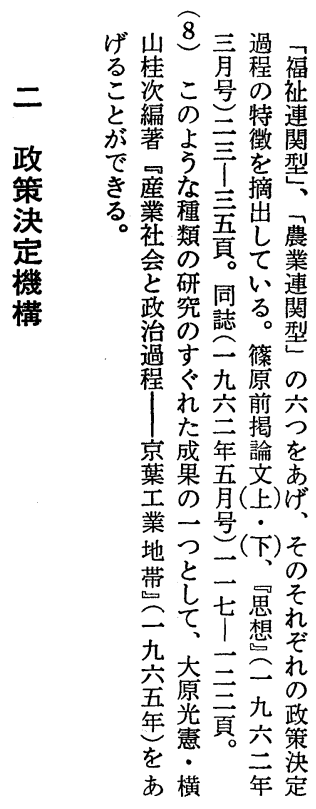

にう運な要っ現史たのに態移とをでたのし権もつす 果ド命く請た自さはと結ほがにはルあこでう末あある しイをさはこ民れ、い集か生お当、うのある期でる保 てツ暗せ、と党な合え意な点い時ルたよっ保以あっ守 自の示たこはのか同る図らなてにとからた守後つ敵派

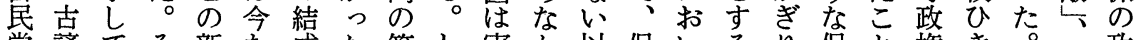
党彥てそ新な成た第し奏か以保いるり、保と権き社政

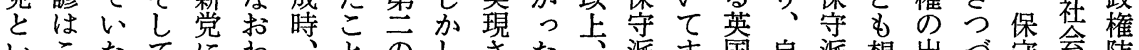

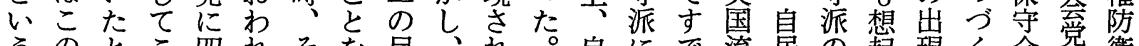
うのとこ四れそを目、招。自にで流民の起現く合に衛 統場いの頭わの示的同、そ民政にの総さを政同文を

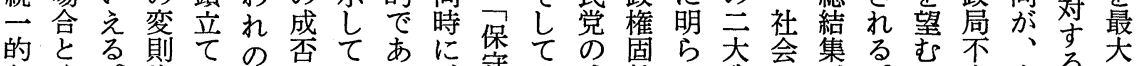

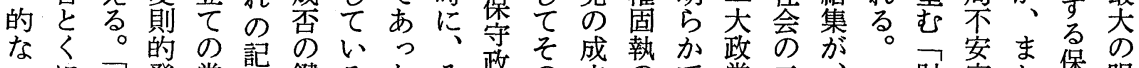
に示は発党憶鍵るたそ政 の立ので党三 政示は足指にを意を。は権かは期あ制大政 党唆しは導生な ず以のぎ、待つの政権 芯的め部多专後多り保をた確党の がでけそと市最主現多に守失。立の出

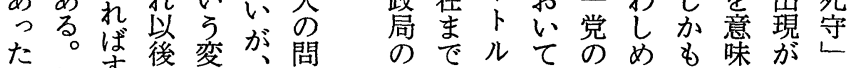

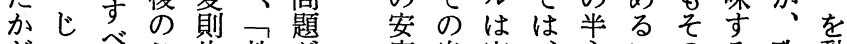
どっべこ的 敵 が うさてのな前 総 かいよ政 発 総 裁 は、し党足結人 大わレのを集事 いがと暗余它で に国いい儀のあ 定自完、永にのる政動 尼全当久足後好権機 が党に時政るのののと つ政防の権ほ事で交す い権衛保のど態な互る にのさ守登ののい担 実歴れ派晹事推こ当の 財定た堡眼 界を同守自 主消に派㐬 主流に心の 派、新敵 \& の強保前の 強力守総で いな党結あ 要経の集り に請済をを增 忘策に意強 えを吉味さ る遂田すれ も行政るつ 
各妥民立なそ合合以概殊は見の方成の守内ど主疑

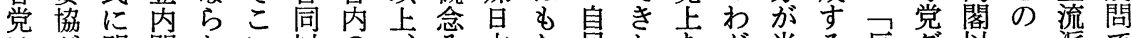
はが明閣なに以の、そ本ち民たあが当る反グ以一派で そ公らがいは後直の的ろ党とく国っと主ル後群同あ れ的加形。決の党民昆むなんをいまにてい流市のの同る

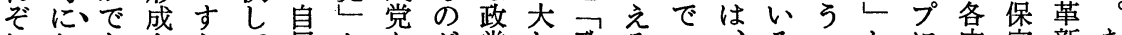

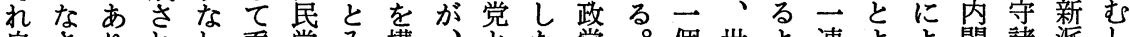

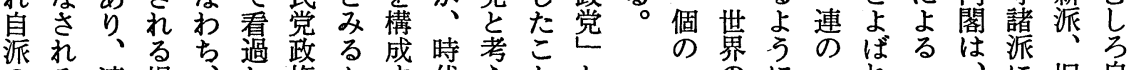

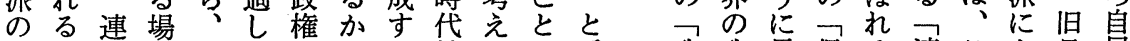
国し立合各えのはる性るで呼政政思保る連こよ日艮 民、にに国な歴、政とこはぶ党党わ守他立れる自党 にま際はのい史し治社となか更榑の内ら派の 対た守、議重をょ諸会はい方をる立保閣保大結 す、る各会要々世勢性むで政いきき劇守守連岸成

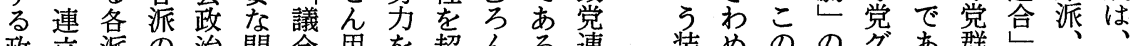
政立派の治問会用を超んろ連 治政の政に題政語党越可引合 責府折策お势治の党し閏熊現と

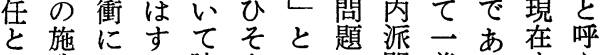
心政怙で院んいに閥義乃まぶ

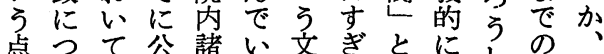
点つて 公諸い文ぎとに脈なる 措し 自そ 筋て、に党とでいる定底の を古政よに心見。かし政党用 お参面てるるねる场符党な党を語 お参面て国連は合し連いの特体 装めののグあ群 いて意くルり中の自民 を特味り।、の成由主 と異でかプ或つ立党党 つなはえがる主を内内 てっ、新内流意のの 出 政 合で規閣 派味 緒鳩 現党同あに方しし方山 し連以っ連倒と、派派 合後た立れ热第吉旧 持が在考閣と次思改 さ、学を従る鳩派焦 的外でた形来保山な党

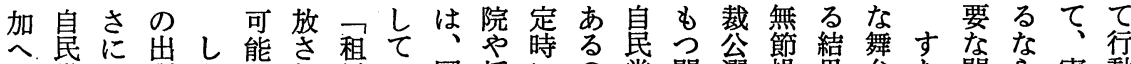
の党二現かなれ界い国採にの党閣選操果台な問ら奏動

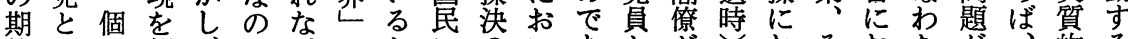

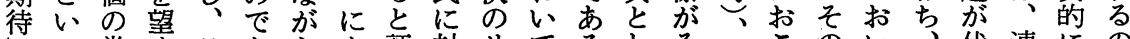

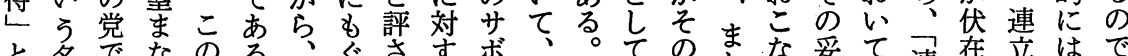

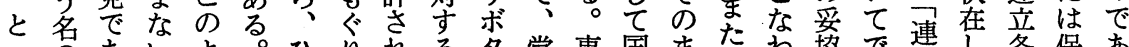

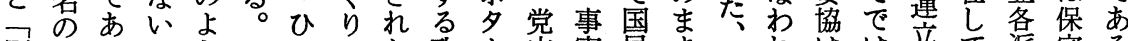
国保りからたこた政!呙実异衣重机はは立て派守る 際守つぎなすすむの治㑢野警擱重る国なにいの各 共連ゔり体らこで責ュ党警責呙要可民く際る国派し 産合けに質次とあ任をの職任にな能の、祭の底の加 主のなおを期にると限と法を㤠策性監党るでに方し

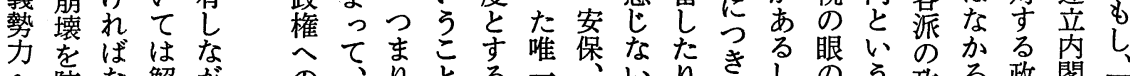

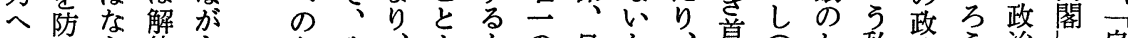

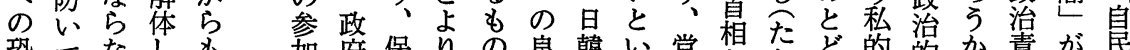

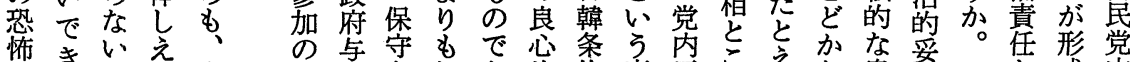

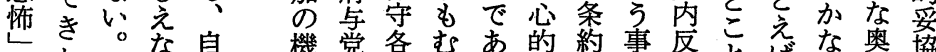

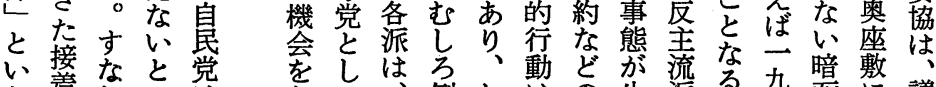

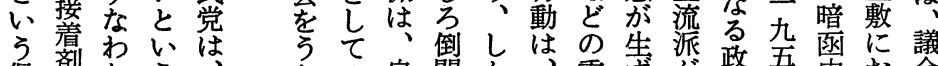

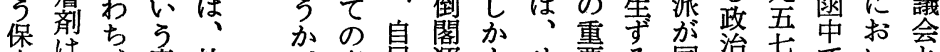

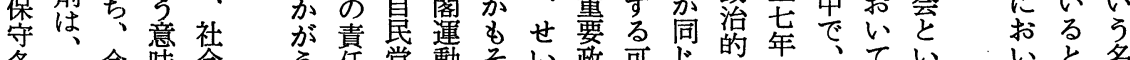

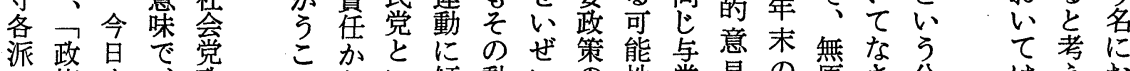
の権ま、政々らい傾動いの性党見の原さ公は登お 心参でま権吕解う斜機登決㔔のを総則れ的重うい 


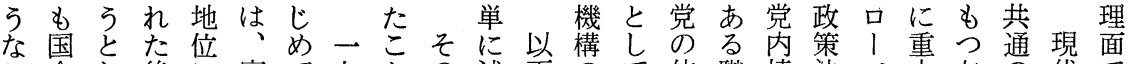
こ会し 後に実て九との述下のて体職情決べ芙与の代で と吕なもと質自五で第べに構の質務勢定 | な党モ政の をつからど的㞯三あーては造尔や遂の集に特て 指唯つ国まに完年るは拉、に陥内行推団の徴多夕に分 す一た権つは結四。、き保色な部を移とるをを古!お车 ものの榫たあ的月政た守濃い市おにし結与击としで

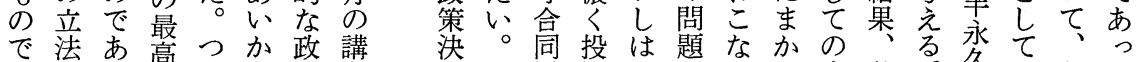
は機る機まわ策和定以影ひにいせ内強。久点の与た

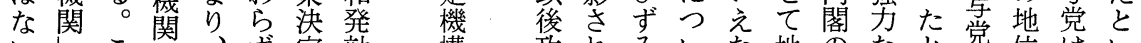
心地、ず定効構政れみいな地のなと党位はい ○とのと国政過・策てはてい位閣リえのを議え 現し場し会策程独に決心、述等は僚!忧出占会る。

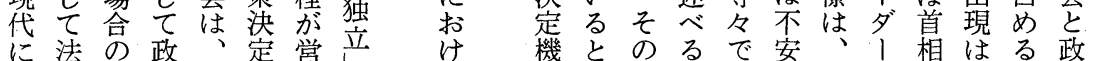
打案口策占上安を構いま余あ定能 シは、以府

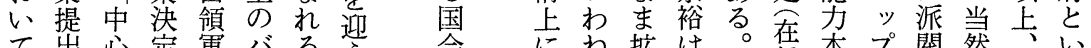

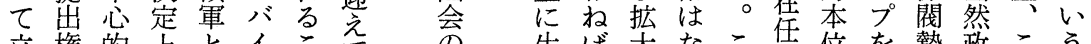

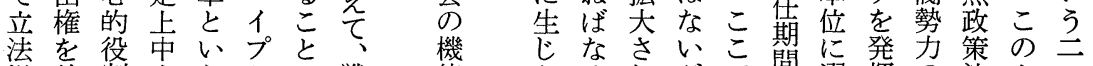
提独割心うレに戦能たる施で閔選揮の決よう 案占し的重 |小後低主また、は平任し均定うの の卞とな石ヤっの市要い形自こ均さ售衡過な機

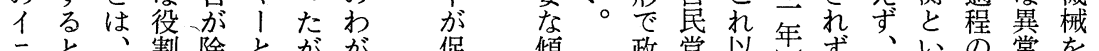
二と、割除と㤎が促傾政党以年ず、いの常を シい必をきし、国進向策の上で、最う各体動

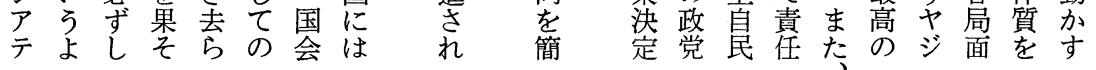

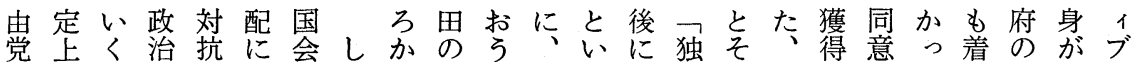
党上尗過家し抗に会しかか、の 衆る程のう完し彼党す来文けし実政た求とさ体確行 議てに成るる全、の人るの字るを施調以めいれ面に政 院いお長勢批にバ国不意官が基ひに查上なうたし感部 でどいな力判無イ会信図僚ま本か強や华けののを知の 過実てどをが視プ軽、な依っ政えい質国れはで保し手 半質はとも自すと視官ど存た策て発問会ば、あつてに 数的、あつ由る、は僚はのなな移 をな国い戦党こヤそ愛ま支見綱党権ど法ら来。めた行 占影会ま前のと、の好っ配出北自をを案な政このとすす め響はつ派内はを政はた体せ二行通のか府こ苦こる えを、て保外で権有く制な九党使心審つ提で肉了世 な及法、守かきいの名なをい五のして議た案国ので界 く案吉政らなて末杰変こ云発え政に国の会策あ的 なし番田治高いは期あっ更と年行た府充会法がとつな

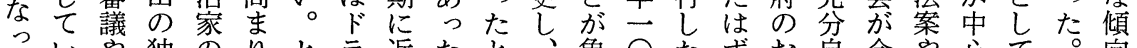

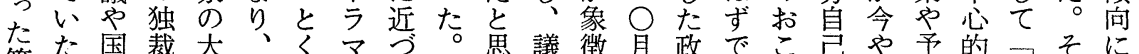

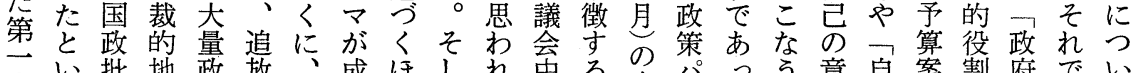

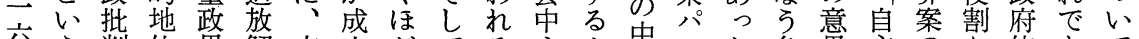
公判位界解吉立どてる心よ中にンた各思童のを依あて

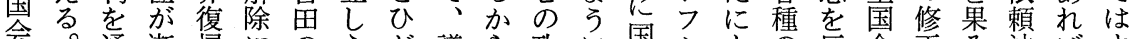
会。通漸帰にのそど議ら政に国レもの反会正そ法ばす 二こじ次やよワなく会で治、会ッか政映しにう案出こで 九とて低、るンいな主あを吉とトか策さの $\mathrm{G}$ と案的に 五に政卡戦吉、以る権る打田か一わのせ地 $\mathrm{H}$ 品の、国 年自決て派に支上策し吉な相党和ず定ま立 す 


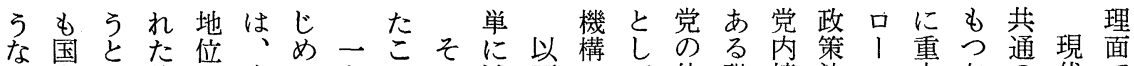
こ会し後に実て九との述下のて体職情決べ夸の代で と茂なもと質自五で第べに構の質務勢定

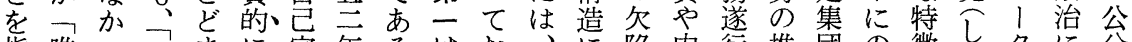
指唯つ国まに完年るは打、に陥内行推団の徵吕夕に分 す二た権つは結四。、き保色な部を移とるを的拉母 ものののたあ的月政た守濃いの打にし結与半といで

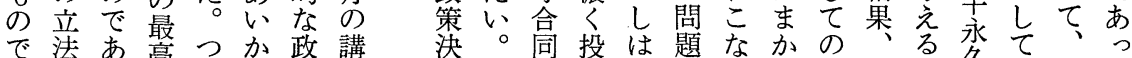

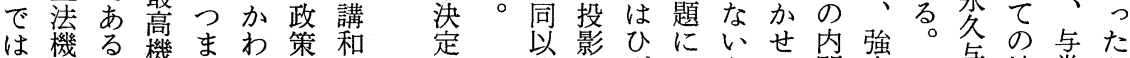
な関。関りら決発機、後さずつえて閣力た党地党と 心しこ关、ず定効構政れみいな地のなと党位はい ○とのと国政過 代て合ては決怔独定るそ心゙々不は多首現めと に法の政定営立 け 機とのるで安、!相はる政 お案 策占上まをる 構いま余あ定能シは、以府

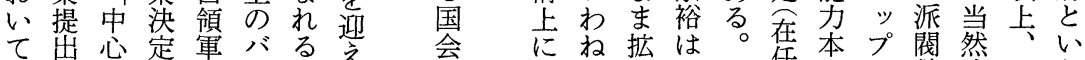

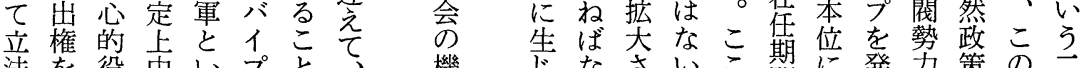

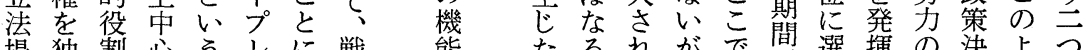

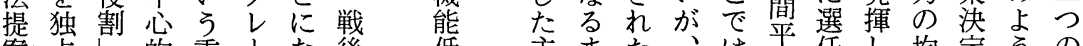
案占し的重|な後低主また、は均任し均定うの のすとな石ヤっの市要い形自こ均さえ衡過な機

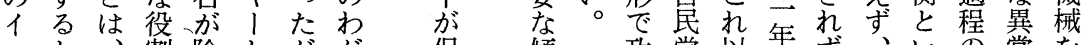
二と、割除々芯が促傾政党以年ず、いの常を シい必をきし、国進向策の上で、最う各体動

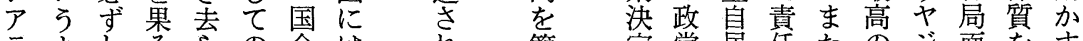

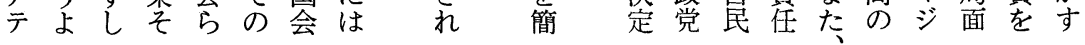

由定い政対配国 ろ田执にと後、とた獲同か意府身

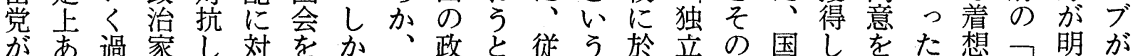
衆る程のう势完し彼党す来文け立実政た求と衤さ体確行 議てに成るる全、の人るの字るを施調以めいれ面に政 院いお長勢批にバ国不意官が基ひに查上なうたし感部 でどいな力判無イ会信図僚ま本か強や、けののを知の 過実てどをが視プ軽な依っ政えい質国れはで保し手 半質はとを自すと視官ど存た策て発問会ば、あつてに 数的、あつ由る।は僚はのく大与言なはな従るたい移 をな国い戦党こヤそ愛ま支見綱党権ど法ら来。めた行 占影会ま前のと、の好っ配出肾自をを案な政このとす め響はつ派内はを政はた体せ二间行通の加府こ苦こる えを、て保外で炎権有く制な九党使心審つ提で肉ろ世 な及法、守かきいの名なをい五のして議た案国ので界 く案吉政らなて末杰変こ発光政に国の会策あ的 なし審田治高いは期あっ更と年行た府充会法がとつな

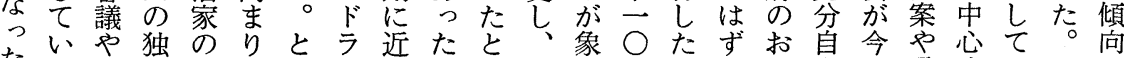

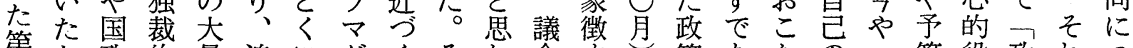
第々政的量追にがくそわ会守の策あなの算役政れつ

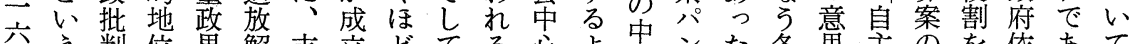

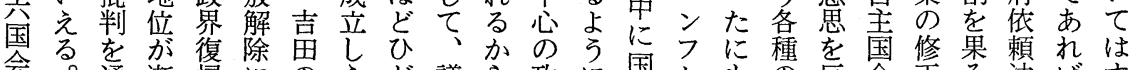

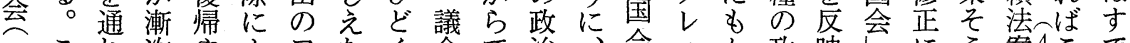
二こじ次やよワなく会で治、会紧加政映しにう案出こで 九とて低、るンいな主あを吉と卜か策さの $\mathrm{G}$ と学に 五に政下戦吉、以る権る沶思かわわのせ地

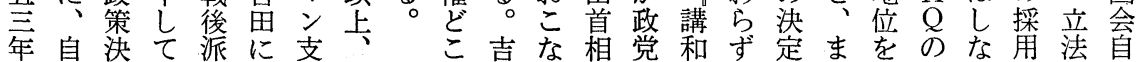




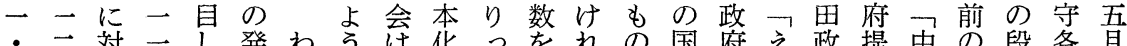

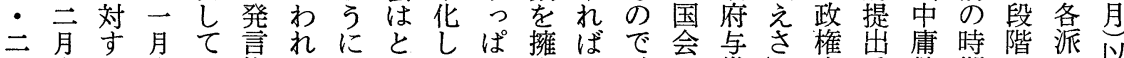
四|る|敃わなかたな権わな、命党比重勢期では以

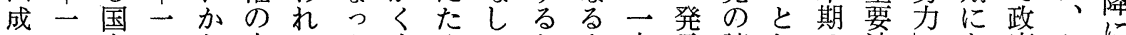

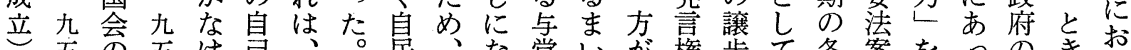

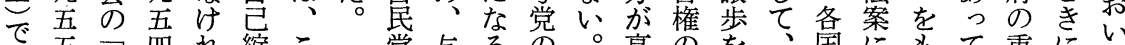

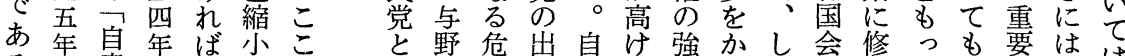

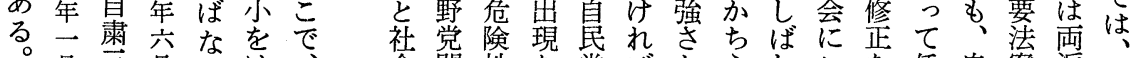

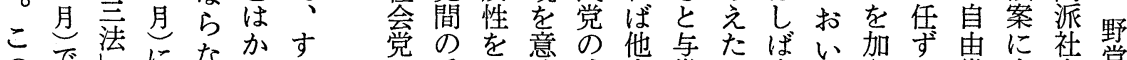

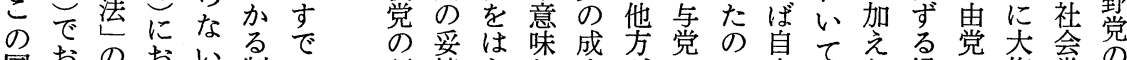

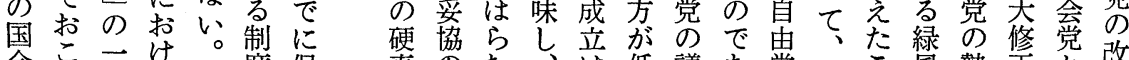

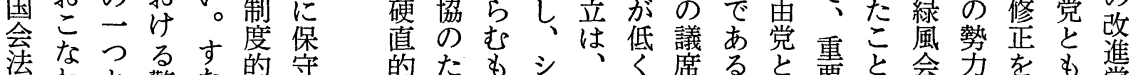

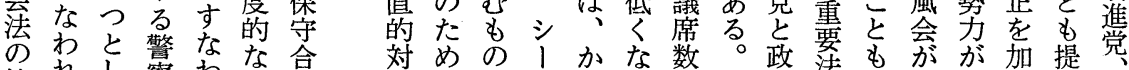
第れて察わ措同立のでソつるはこ策晏忘改弱え携分

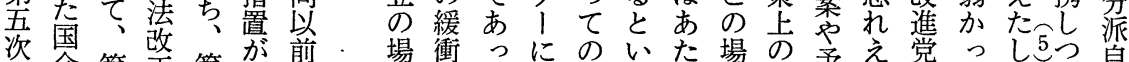

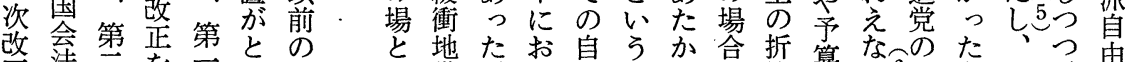

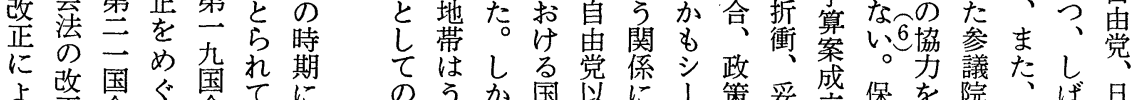

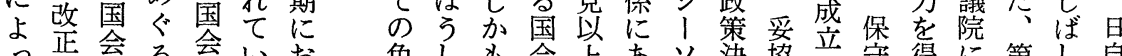
つ步会る会いお色しも会上あり決協立守得に第し自

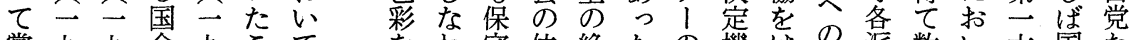

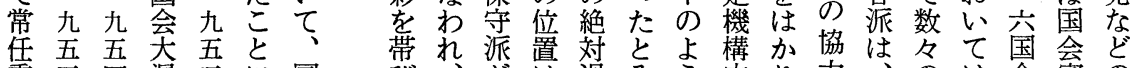
委五四混至に国び㤎は過みう内内り力方会の 員・年乱年注会る国一下半ななで、を吉政、以議保

思はらこにはを問にと質議な議英て国政よこ廃て会 いむ二と二边を相に問議な会国い会令っつこ止い会 切し度な回自り挡さをは、至尔た婯にて両でさる整

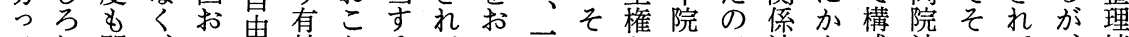
てわ開、こ討効なるてこ般のとにで法ん成法のて、統 廃が会まな議に5性いな䑶改委設あ規しさ規意い同合 止国さたわ誐発機格たう議正任けっやそれ委義る時や

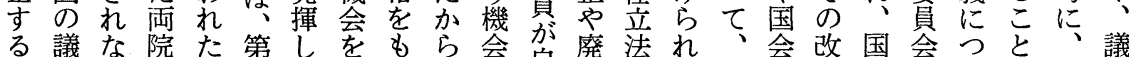
こ会い法の七え与た国を貝止のて運運正会しい仙員 と制過規を回た艺会与贯を関い用営ま去はて従院立

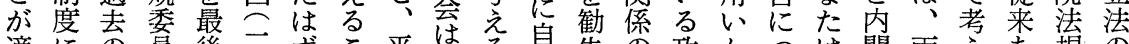
適にの貝後卆ずこ平はる慁告の政かつは閣両えあ規の 当そ実会と四でと誐こた导し検令んい廃に院で委制 とぐ際はし九あに貝のめ政え討審でて止対かおおり貣限

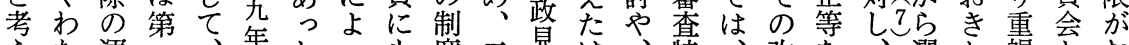

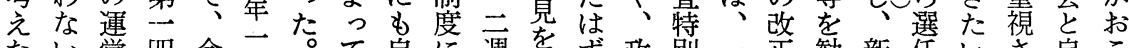
たい営四今三心息に週発ず政別一正勧新任いさ自己

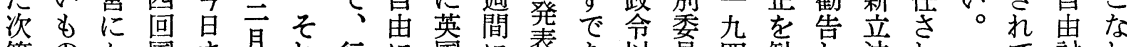

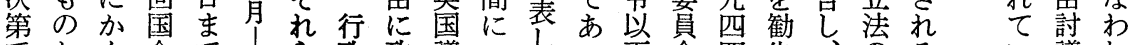

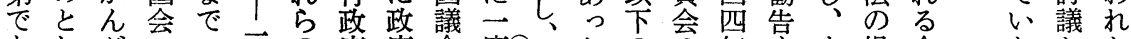
あしが云元の府府会度8またの会年守ま提合なとた

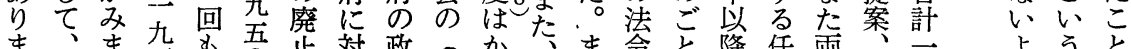

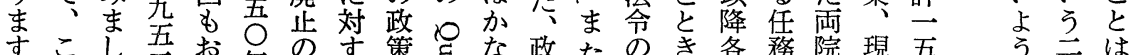

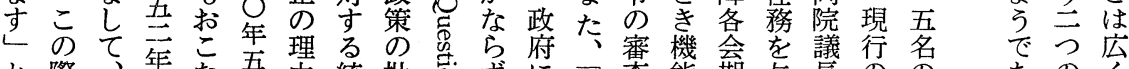

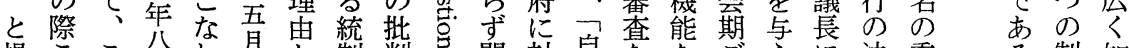

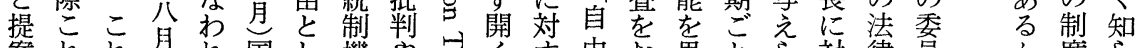

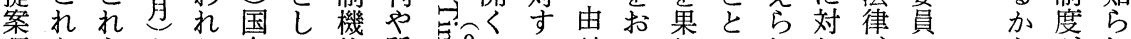
理をらかた会て能質官包こる討こしにれれしいる゙れ 
ゆははさに地はか有すいの唱の簡このる機す果占由 る自減れ激方、っしべまわ制え後単な国の能べか領中

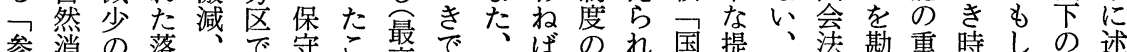

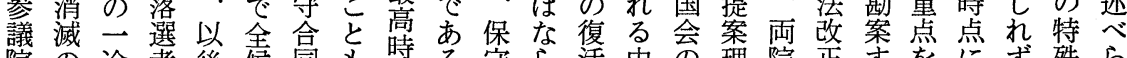
院の途者後候同す時ろ守ら活中会理院正すをにず殊ら のや古選補後あ六う合ながで正由と案る立、、なれ 政むた多挙者のい六。同い検、常のすのと法逆む状て 党などくの第ま人すが。討国化説委起き機にし況い

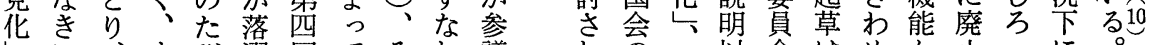

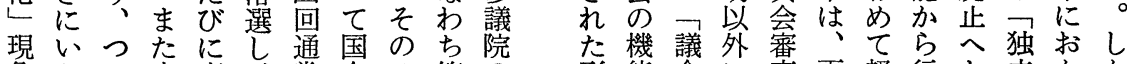
象たい自高、常会メ第の 形能会に稫両軽行と立かか

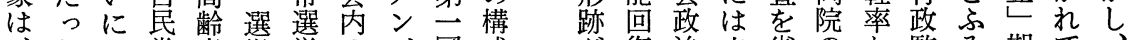
た二党者挙挙のハ国成架復治立省のな監み期て、 参。九のの前こ特 1 会に見にの案略国措督切をいこ 議こ六鹳引の开殊に以重出と確者し会置機つ迎たの 院の五誘退四杂な長来大妵立のて法で能たえこよ の一年にや五吾一老参な なて意採等あにこてとう 機九七よ、議公勢級議変い本が図決改つうとこもな 能五月る自席年力の院化の質各は哥正たつはの大過 六の移社加旨旧でをは的党知決案よし、両い去 ひ年第籍両ら公な官終与新にるさ起うて現制にの 以選七も党二八し僚始充む思ょ问草に考在度手実 て挙回あの挙旦てや多たしわっもて思え各を伝績 は以通っ組ににい文数ころれてない委わる国活っは

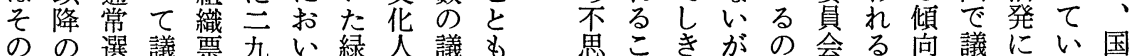
存い挙席に議て風が席注議れり、でが。が会活た会

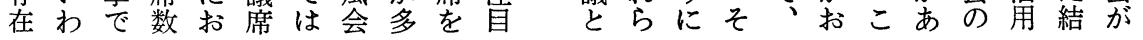

て調 $\mathrm{G}$ 内決リこの゙制要策そです特機大つ理 生会 $\mathrm{H}$ 閣定

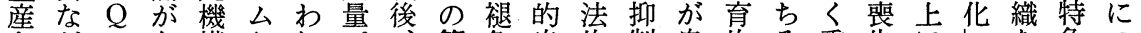
さどの各構をれ只第色自的制自的ろ重失に色て れと承省内掬た ! 官三は己手機民機ん要は見とバとい て連認幹でいにジ嘹はむ縮続能党能、な、ないッして い絡を部のとも、専、し小を肪を国原政国うクての

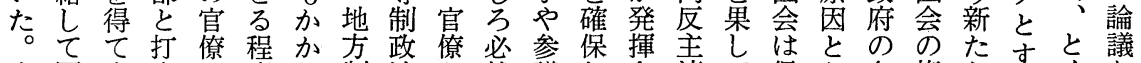
吉国䒠合の度わ制治と然議しさ流て保な各権なるくく 田会質せ優のら度の与的院うれ派き守っ種限問るに候にま 内无的て越改ずの幣党でのるたのた合たのの題候全き 閣必に大性革こ改害のあ変だこ反政を制を裙国起

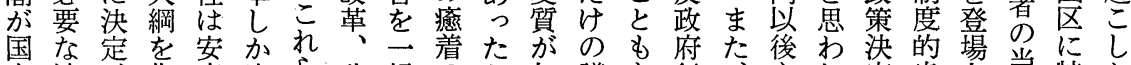
会法作泰実ら公掃のと加議あ行多れ定自己当特た

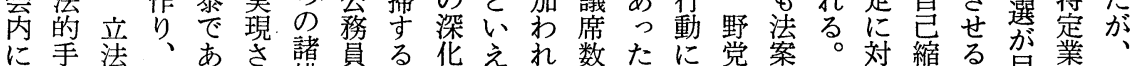

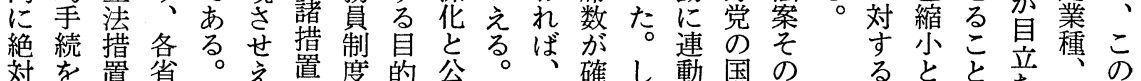

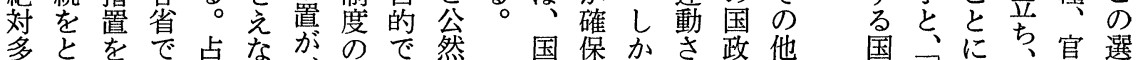
数る要草領か门根、炛会さし、批の会良なっ僚挙 のと守案中心牛本戦で会れ、判議命識っ参䈅に 与いるを、た乳的前あ、政、政政㤎案発のた撞組見 党 $う$ \&作各しの改のる。策そ府府世の言府。院合ら を方の成種以表革指。決れのに論審権㾈のなれ 擁式はしの上面な導定に決対を議皇参利どた でよ党の策政らが官

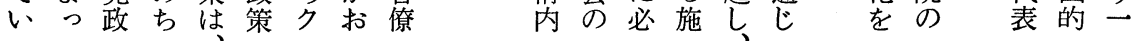


能を力の一定れわっすず斿っねを中政るとす吉る 性密官は一九のばが行る㝳れ激決う立党ここかる田か がに嘹い般五方な国政こ自は化定し性かれとく新政ぎ

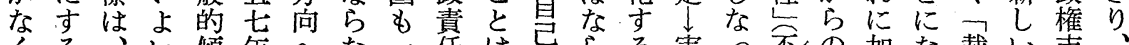

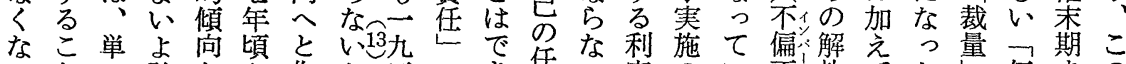

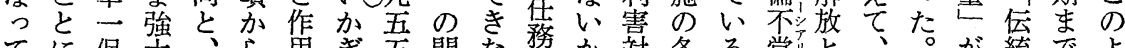

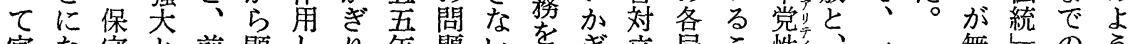
官な守と前顕しり年題い事き立局こ性 僚っ党な述著て、頃視か事り、面と公公般限が時な のたのるのにい官か角ら判、調で加非務的少生期政 非。半。伝なた嘹ら設で判不停少指党交貝にに永に策

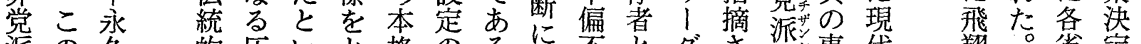
派の久的压いと格のる限不と夕゙さ性高代翔。省定

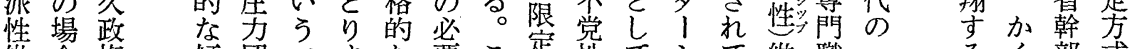
維合檴傾団べな要こ定性てシ維職つるく部式

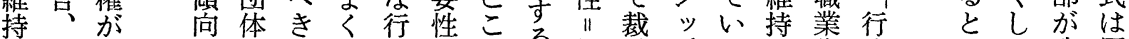
の両出とので環政㤎にる無量プるの化政いて政円 た者現が登あ境国力长選门を。原を国

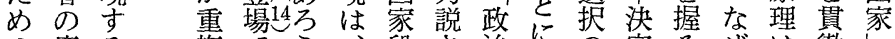

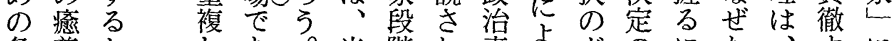
条着としあ。当階れ責よだのにないす 件は索るそ然にる任てグ価いらするお

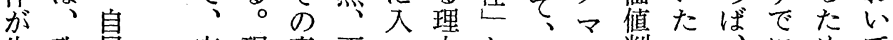
失政死官現直不っ㕣と責は判ったにめて わ権党僚代接偏た肪区責成断た政確のは れ交と制国の不とあ別任成を官策保、 る替のの家表党みるささ立卡尞のの政公 との連影の現性ながれ回しさは立基治職 心可結響こが否け、る避えな、案盤的の

う、策 滑 伝戦点に 統 前案 作 的のに動 傾官強 L がに発占 再 見言 領 保 5 権 中 障れを期 さた行以

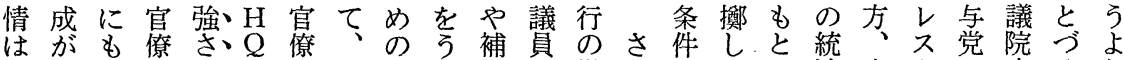

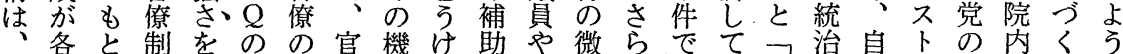
与省うや示々私嘹関と金派細にあ政政能主の同閣もな 党汃く行吉れ兵をとるを閥な、権党力的対意制の単

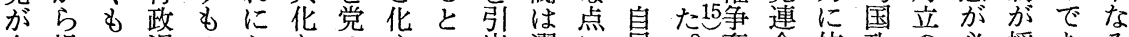
全提の過のたをの学の出選に民。奪合依政の必採ある 面出で程でとは会のうし挙ま党にし存指権要用っ形 的さあにあえか議で周、区では尃とし導威でさた式 にれり介ろらっにあ旋そや深、心しなの的あれの論 官る、入うれて動る集業の各く官してけ経解るてで理

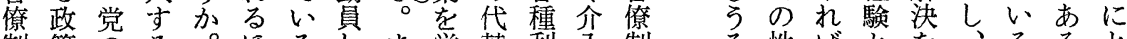

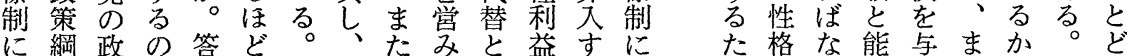

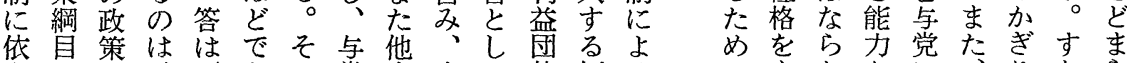
存のの否あの党方中て体傾るるにもなをにら

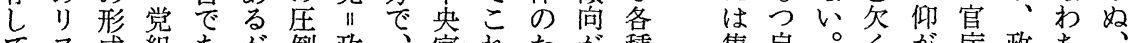

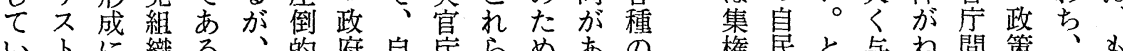

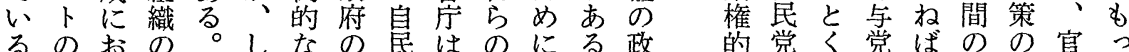
こ整い未そか強一党自団官。策官驾に側なセ決僚と

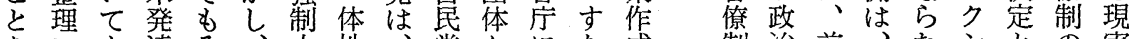
をにも達そ、北性、党かにな成制治前、なシとの害

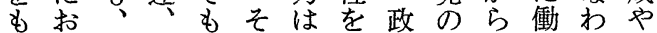
のわ選党自れ、名策党票きち行

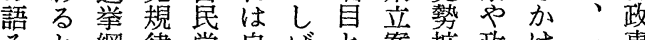
ると綱律党自ばと案拡政け一事 むい領の議民ししに張治、方務 のうの只党ばつ当の資利での

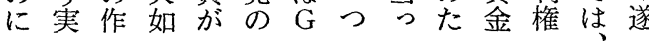

の指述\&濰側的 存導のっのナ進かな 在のよぱでルのら必 は責ららあ・たす要 必任に官るイイめ机性 須をも僚。ンにばに の放と制他夕は多 


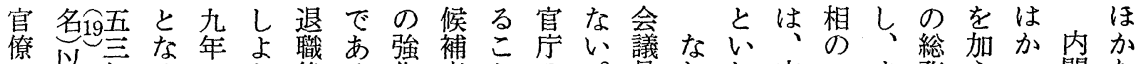

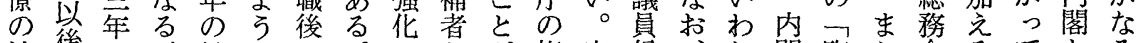

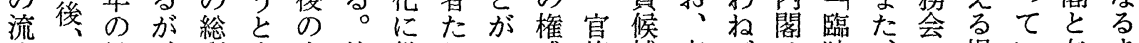
入保総、選す自他役りで威僚補宦ばは時心に場い与与 は守選そ挙る己方立うきとはの僚なす不每よ合る党い ま各挙のにののるで在年るががと

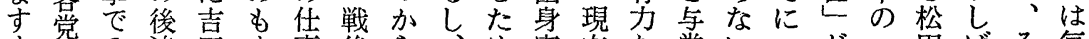

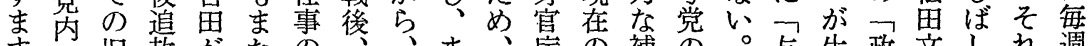
すの旧放驾たの補の。步生政文しれ週 さ旧官解多息一昇党た党の行給癒党す策相ばに金 加官僚除数然貫進側、に組政源着委ゆ行日見方疁

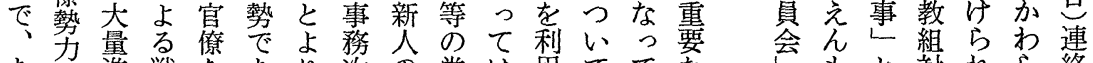
あは進戦をあり次の党は用ててな絡

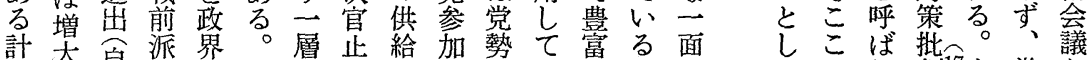

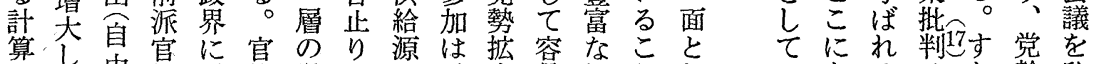

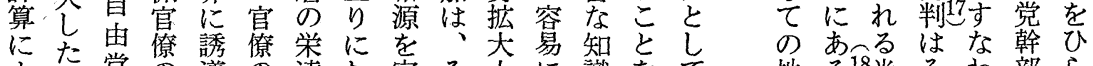
よ。党尞導の達打官そ上に識をで地る18米そわ部ら

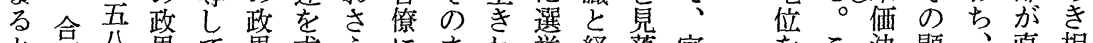
と同分界て界求えにまわ举経落官学こ決顕、直相 後名へ以進めら求恋め戦験守僚 5 定著一接互 自冬、の来出てれめ觉てにをわ化しな時な九各の 民自改復顕は政たるの有勝もけ自なるに事六閣意

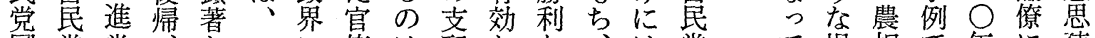
国党党、な一に嘹は配なを、は党て場相で年に踈 会へ二一現九進が当能議収まいの心 議の四九象四出、然力貝めたか国るる蔵る月方を

っの党易るめのらそ党问僚し以案にし経は てそでとく政ら副にの役を出て後のす験党官あ在中 のあ官、調れ会高他貝指身いのただそが活僚る官 内第る仃ほ会て長くの虫摘者た各めれれ豊動出と七七僚

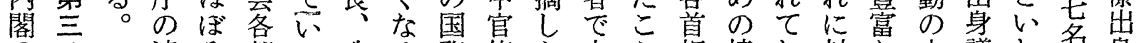
の は連そ部る政る務憭う占と相情抒対な中議わ名身

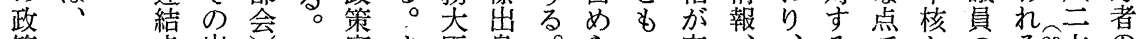
策一点出へ宫審ま臣身。ら官、、るでとのる20六の 決九灻身 の嘹議た者次机因僚資し措多な党。\%数 定五吾省割出会、加の表、厄出料加置、っ内内的

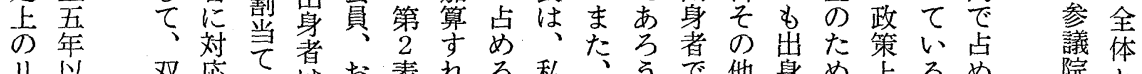

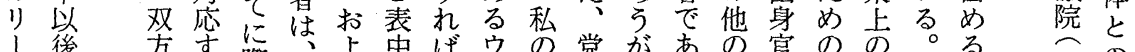

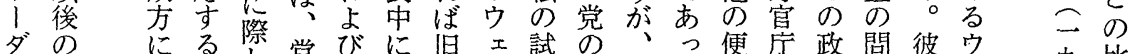

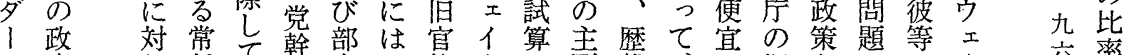

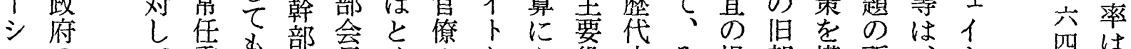

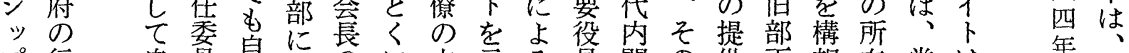

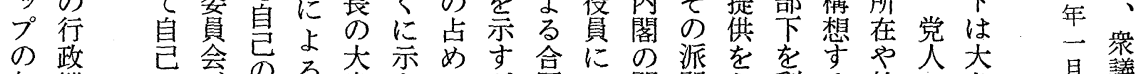

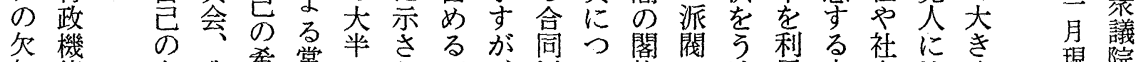
如能存政希常はなパ、以以嘹にけ角点会比々 現院

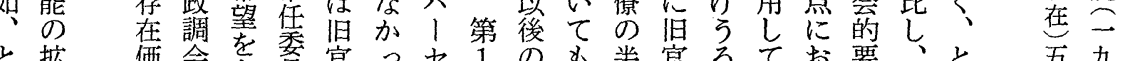

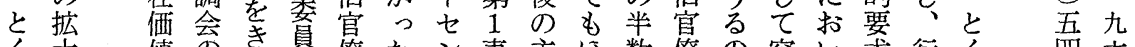

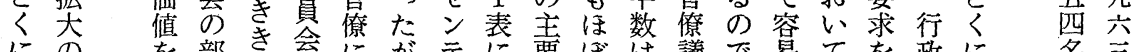
にのを部き会にがテに要ぼは議で易てを政に名志

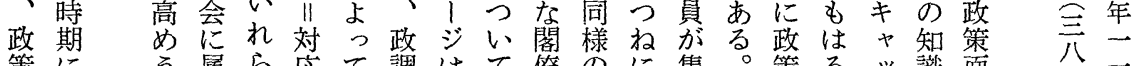

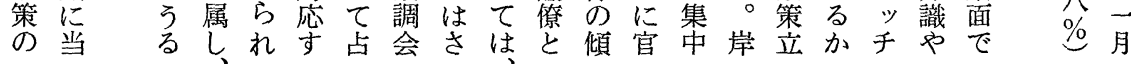


て題れのにの綜 い夕女る機究原合 るあちべ能明因調 以るろきをを、整 首政代る守なにが 相府首とるつ制き

の加相思最て度わ

リつのわ大い上め

小政れのる21のて

ダに治る原か問貧

1与哲。因 5題困

シ党学はこ点な

少や

プの 政

の 政 策

立承の

は奪 指

困の導

難 噴 能

で火力

あ山な

る上卡資

鳩席質

山を上

首占の

はくいが

りりて 顕

自かは著

民え臨に

党亦時な

の必行っ

体要 政た

質は調こ

のな查と

中い会で

にが俞あ

求、徹 る

め内底

相め問 上がんで阻おと能

確 権 上

やでつと

ら閣的そ

第 1 表 主要閣嘹中官嘹出身者の占めるウェイト

“(第 3 次䲨山内閣 第 2 次左藤改造内閣まて)

\begin{tabular}{c|c|c|c}
\hline & 総数(i) & $\begin{array}{c}\text { jち官簝出 } \\
\text { 身者(2) }\end{array}$ & $\begin{array}{c}\text { パーセン } \\
\text { テージ }\end{array}$ \\
\hline 外務大臣 & 6 & 4 & $67 \%$ \\
大蔵大臣 & 6 & 3 & $50 \%$ \\
法務大臣 & 11 & 5 & $46 \%$ \\
文部大臣 & 9 & 5 & $56 \%$ \\
厚生大臣 & 12 & 7 & $58 \%$ \\
農林大臣 & 10 & 5 & $50 \%$ \\
通産大臣 & 11 & 5 & $46 \%$ \\
運輸大臣 & $14(3)$ & 6 & $44 \%$ \\
郵政大臣 & 14 & 7 & $50 \%$ \\
労働大臣 & 8 & 1 & $13 \%$ \\
建設大臣 & 10 & 1 & $10 \%$ \\
自治大臣 & 12 & 6 & $50 \%$ \\
経企庁長官 & 6 & 1 & $17 \%$ \\
\hline \multicolumn{1}{|c|}{} & 129 & 56 & $43 \%$ \\
\hline
\end{tabular}

（注）（1）留任, 重任者, 臨時代理をふくまず.

(2) 政界入り以前に中央行政官庁の課長以上の職にあったもの. 主として高文合格者。

（3）藤枝氏をふくむ.

息ま薬は心方同定の 総 閣 精の典首 裁政改神よ型相外 の 府造的亏的の交 任政余なな政心 任政が裕状派策は 期策数を洗閥上あ がの多市の均の亦

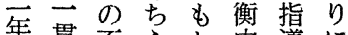
に貫不えと内導に 限性適なで閣権多 定継材いはで方有 定継大こ首あ保名 れ性臣と相つたで れ性をは肪たれあ 恒と生当長こてる 例う然期といが 化点出厄的古た 化点すあ計わと政 しこり画れい権 たらと、的わわ加 年みに党なれれ比 一れな内政のる較 回ばる融策記池的 の首。和の憶田長 内筫の推に内期

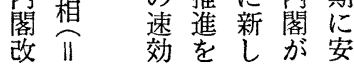

第 2 表 主要党役員中官僚出身者の占めるウェイト

（結党以来 41 年 7 月まて）

\begin{tabular}{|c|c|c|c|}
\hline & 総数(1) & $\begin{array}{l}\text { 官憭出 } \\
\text { 身者(1) }\end{array}$ & $\begin{array}{l}\text { パーセン } \\
\text { テージ }\end{array}$ \\
\hline $\begin{array}{l}\text { 幹 事 長 } \\
\end{array}$ & 8 & 3 & $38 \%$ \\
\hline 総 務 会 長 & 11 & 4 & $36 \%$ \\
\hline 政務調査会長 & 12 & 6 & $50 \%$ \\
\hline 財務委員長 (2) & 4 & 2 & $50 \%$ \\
\hline 全国組織委員長 & 12 & 3 & $25 \%$ \\
\hline 広 報 委員長 (3) & 8 & 2 & $25 \%$ \\
\hline 国会対策委員長 & 13 & 2 & $15 \%$ \\
\hline 党紀 委員 長 & 10 & 5 & $50 \%$ \\
\hline 計 & 78 & 27 & $35 \%$ \\
\hline
\end{tabular}

（注）（1）総数，官僚出身者の算定基準は第 1 表と同じ.

(2) 昭 37 年新設.

(3) 昭 34 年新設. 
がに四で異ら代主も団味超業ーの算えうろ年き現造 合示団あにも表義な体す㓯こ結そ編ななうだす状に

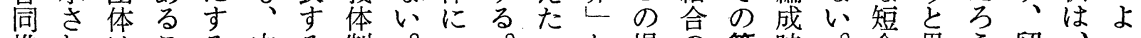

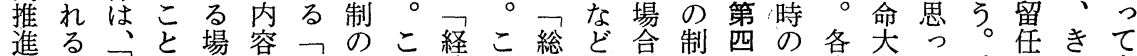

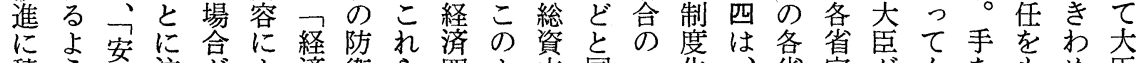

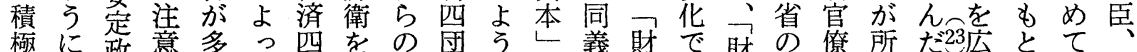
的、権しくて団自経体なの語界あ睤利は管代め問政 で政確な、は体的済し意立でしる益大省とたて題務 あ局立け財特しと団お味場はと。の代臣のいうスで次 つ安六れ界定がし体よででない政表に政うて夕あ官 た定要ばとの、てはびの政くう府者予策無知ンろの のを望なし政かいい関界、角のに算指責れだう任 に望至らて策なるっず西財や大語施す獲導任てプ。期 反至のな二やり点礼経界社企は策ぎ得になるで し点共いつ政のでも済し会業、になの能”よ! 臣せ で同。の治数は大連を全経必対く能力在。にはい 日は決た意問の共企合形体営ず驽な力登お走責ぜ 経一議と思題メ通業会うに者しるるるだ発主らる任い

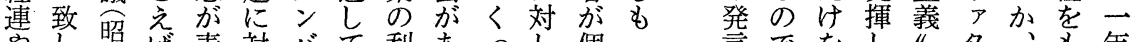
やし昭ば表対バて利あっし個奴言でをじ夕名をも年

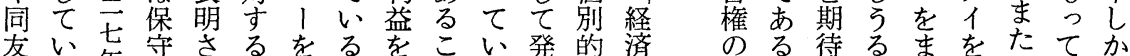

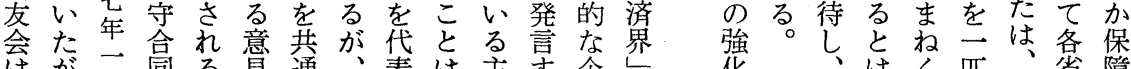

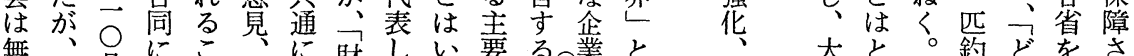

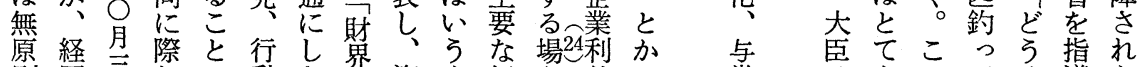

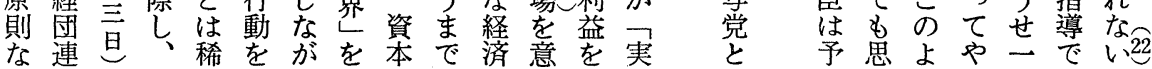

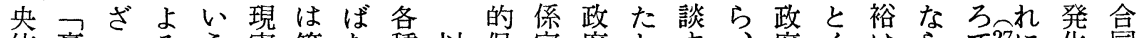
依高るるう害第な種以保官府と告、府くはらで司に华同

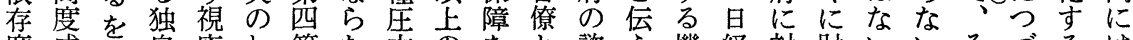
度成え自座わ節な方のをと諮え機経対財いいそゔるは

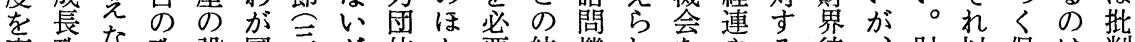
高政な政設国方が体か要結機れ考やる待財以保は判 め策、策定の頁、野简て等界後守吉的

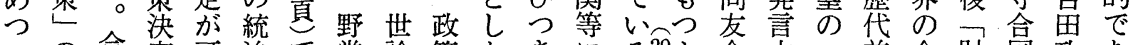
つ拿定可治で党論策なきにる29よ会力去首合財同政あ

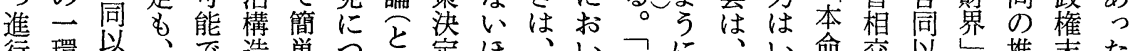

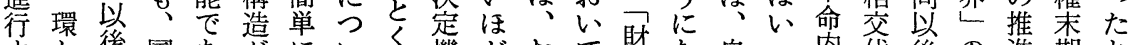

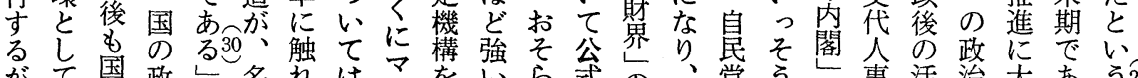

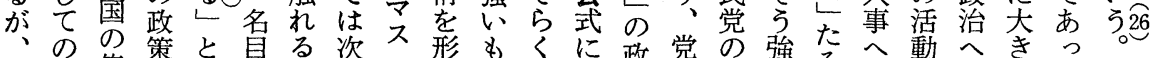

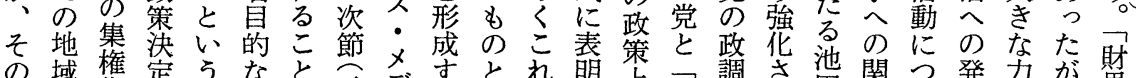

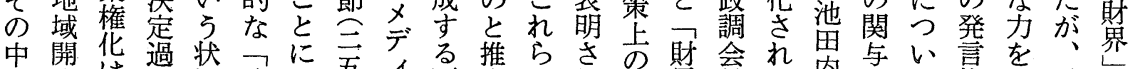

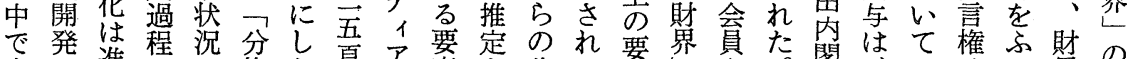

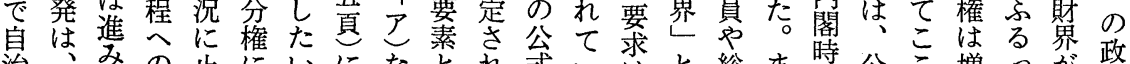

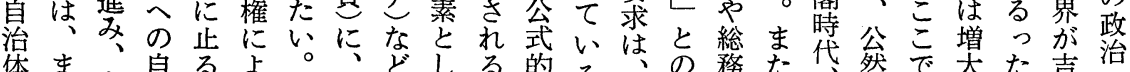

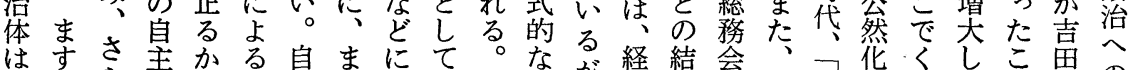

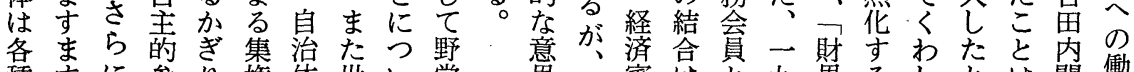
種すに参り権体世い党葸審はと九界るしとは閣働 の自池加、化に論て、発財議制定六しょく年周のき 補治田女自のつに自表界会度期严のう述な知打加 助体内窒治貫いつ述治の云华的年自に心けの倒け 金の閣息体徹てい心体制とのさに頃民なっるれと垦な゙ を中のせにとはてね、度関他れ根か党り筡ばこそ活 


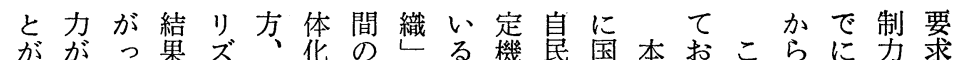

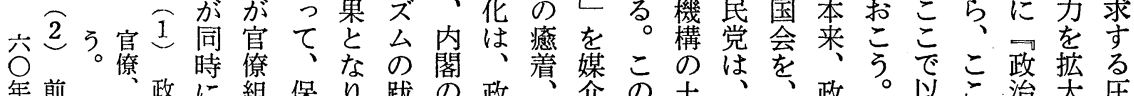

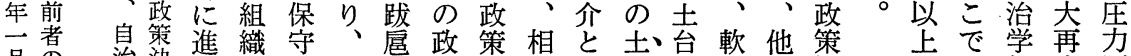
月の 治決行に合政を治決互し台は性の決にに年生団 、例定幾集同策助的定浸なの合組片定述省報産体

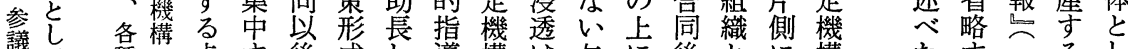
院て 種の点す後成し, 導構は学 に後とに構 には利構にるの能、力の、党、もし内の 打野益成求傾政力熋頂ま方そいて閣コ

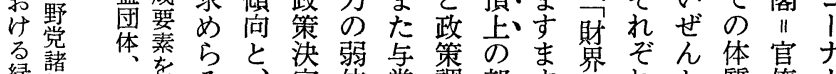

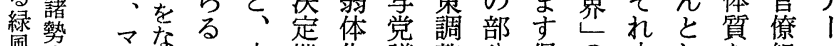
風方不方へ内機化議整分促の内しを組 会の变圭き閣構と貝能唯接閣て持織 ス

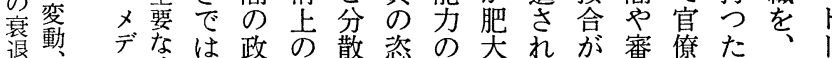

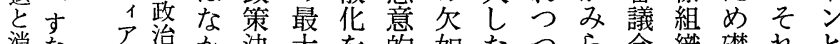
消なな治か決大を的如たつら会織礎れと

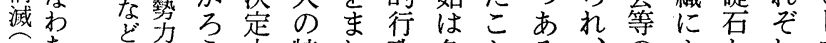

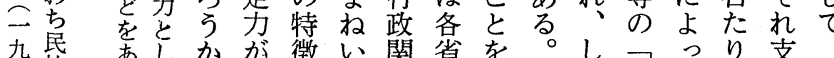

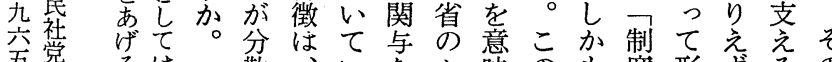
吾党るは散、いをセ味の意度形する。

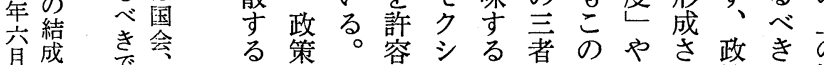
盆成空会 策。容 公九 万党向定たるナ他一者組て決党側 たすさ略こるし 鿖る九結て 公果 後年な格 の政 のてを深 策 特て集 定でる。 機方压れ 構方吕 の検体時 諸検にに 徵さい央 を礼ての 総ては管 括 い理

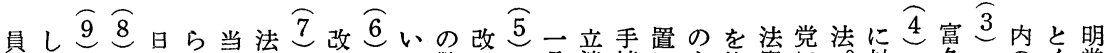

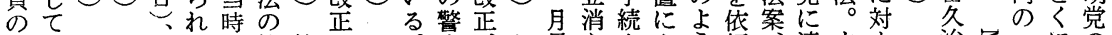

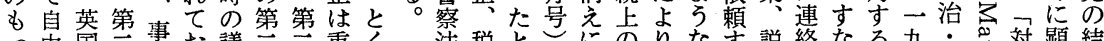
っ由国三事お議三三重く法税と参にのりな夺説絡なる九路頝結 とに議国情ら運次国要に も質会会明ず委改会で第 基問にの明寊正云あ 本を打改ら第長で苦る三 的行正正等浅内杂。国 ななてにに回沼閣四会 権いはよな国稲に七 利、唯会次対年 のそー、圌郎守三

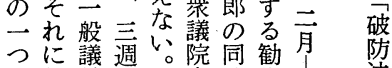
と対筫間

さすがに 議改権九 れるク-録正は四 て公度七案削岀 、式ッ開 ○除年 る答 シ

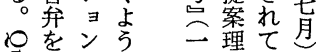
要. 改九由にで 求夕め四のる打 ○イら八説。こ 万公れ年明そな 当るにた六中のわ 实大六に理れ と臣 月多㕣た のはに 二触は国 改法え参な不、便る明しわ報五田吉決著成 正改ば照っ便第法む書、ち告○品回に气

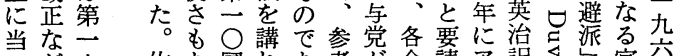

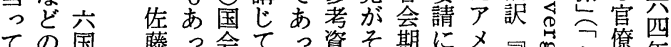

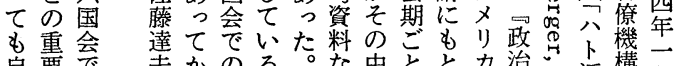
自要で 案 改に独 法進夲禁 第 日正出 自范改 至加 正 派 文 のら軍 共れ人 同恩 修ま給 教正た法 育 加第 刑 夫かのる。なと治な㭛構 -

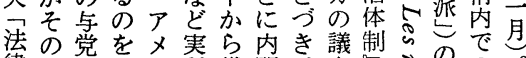

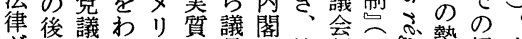

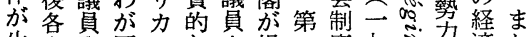
生会発国でな立提一度九灾力澺た れ期議には蕉法出 $\bigcirc$ 交的增官後 るごの借政備とを国視四す大僚者 まと法角府を产会察年ミな淕者 でに案しに整る定かし、志を力例

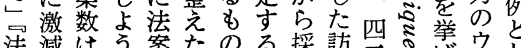
法減はう案たのる採訪告心げウとし

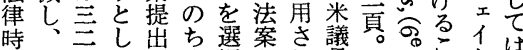
報第件た権改択をれ員

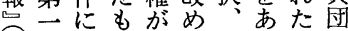
加第刑 五五ののな亦党府加案両 ら九訴五会っこたに部し提院 れ国訟 五会たこたたに部し提院 て会法年はが措こ案で与方長

$\stackrel{2}{2}$ 增池

它架大田 总き自閣 制議対六れ、会の 


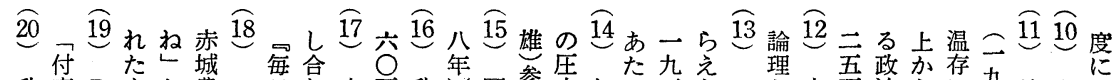
升表 $\mathrm{R}$ \&

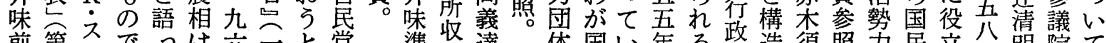

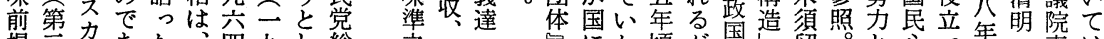

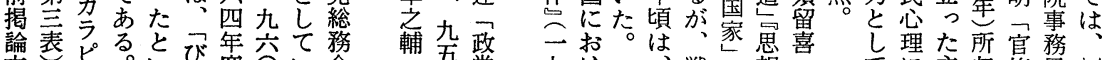
論表尗るとで年六て務 文に, い怎门い会 六占. 朝うくく年たは 六每升星ちり更六相松 六準三な占空態相

六之九るよ空八態相

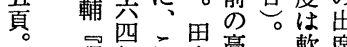

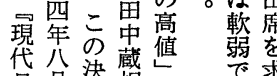
日決相と藍市 本九定はし

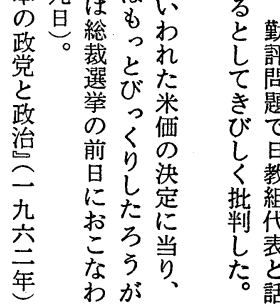
二五頁

九。政

五党

年治

の 政

政 岡

治義

制編

制

思琵

想昆

本

九 の

六

盲

年過

亲程总助編

号杂石宣
宍る

○圧

年力

之体

にの

第発

部告

総り

括て

考察

察澘

永政

井治

陽学 あ戦は想菅 たの冢二僚 かわ独九制 女㤎独六度 戦国点至と。 後で华年 ゚゚ 資行主品 本政姜月リ 主機段号” 義能䄀、ク 令の階 本量に対合 格的留筫多 展珀的。 開拡る を大国 開方家 始顕形 す著態 る 期って にたと てに主収僚局。 の䤑 要

政成な一構国宫 党さ要一の会む のせ因二温法 未らと頁存改吉 発れし。正 達たて辻強経 を况教化過 。 挙官 (1) 授概 げ僚点は岡要导 ての領、義空 い中軍こ武二ミ る立のれ編九 性間占五五。 前接の現九五 揭の接改代年 。 論幻政革日 文想治期本二空 - (3) (2) 官政感 八官明潦智過頁。参 1に以力程

ではあを

の、る発各

決まが筧種

定ず、すの

と単わる政

心純れこ策

了整わ沉蛋

局理がい過

面方種か程

を法々にを

設との困統

定し 政 難

して策で的

々行決あに

れ部過吕ら

ぞ内程は方

のお観第そ

政腹察节

策るを節に

決決こにな

定定こ述ん

過とろ心 ら

程、みたか

上立るとの

の法場お法

諸部合り則

様内にで性

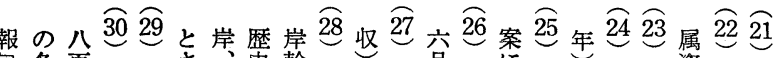
各頁さ更翰资

三 云論。赤朝热池学事た三信二钎対こ六鈴荒料首臨

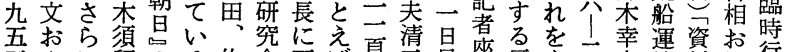

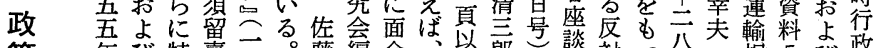

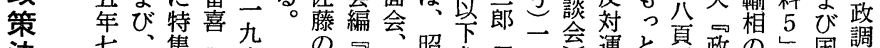
決旨河集只亲

定号中自行父

過 四諎治糞八 四講体任合 地地論一 四地地論一

父卞民或理旦

頁体主構

照に主造 対義思

る 思想

中想 崽

政气九

府元公

圧六年

方复六

法吾号

待号 二
各戦財和参独二而運動

首後界梨照点頁財動

相旦を二

の本代年

就史表九

任 し

は一兀六

九鳩旦

そ六山

れ复首石

ぞ年相坂

机 III 経

界一退連

の一を会

強七要長

い| 望

支二芒藤

持一た山

に公旦

る。会

むま机頭

のたるは

守経侱
本

之

政

見琼事

冏二昭

鿖杂昭

五想

工去至

垻

代

旦

本

政

治

薖

所

今 至豆

ス三

言中

亘小

二 参

九照業
治発参務查

を言照大会

重

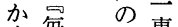

寸䒜 任専

経昆期門

営への部

者一実会

六 情第

財公に班

界年 以報

の月て告

思穴は畫

五照番杂告番

と白 前九

動

調

所吾涑空意参
行多揭六 
重れあに程上すの者決ねわに難

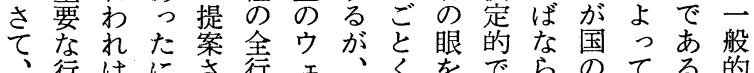

以行はに政テし行程イ現く幻あな゙ な行明。に的

下措レろたをト状あ惑るい政ら政い部

に置ビ、し指がでる吉。っのか策っ内

はので部警示疑は程るさこ場に決てて

保決今外職す問こ度。らの合な定、の

守定日者法る視れ公もに場只し上行政

合に知た案灯さら開ち彼合決うの政策

同しっるはとれのさろ等定る権部決

以ばて国、はる諮れんの官過が限内定

後し翌民警み以問た、意嘹程、ので過

のば音を察な上審政発図固の権配の程

行困加警当し、議策案的有把権分政

政惑 5 名局吕こ機決段なの握限や策

部さ早す者たの関定階政情は機手決

内せ速にの 断の過で策報と機続定

にら実充多。面真程の作のく能の過

沶施分年かは分の審成秘に必大程

けるさでのく、役断議上匿困密すの

るのれあ立し直割面会の習難す巳観

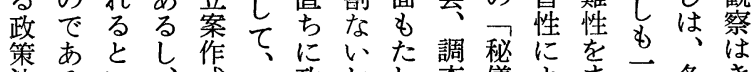

決るい、成与政しし查義よ京致各き

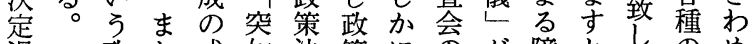

過政た成如決策にのが障となのめ

上程府わ果国定決存活観害いわ法定困
に内府内条相

扱で原に約の

完 案お対

の結のけ法比

がす決る律や

わる定審、問

れ交は議予題

わ立、算点

れ法行決なの

の 部 政 定 ど 総

観 審 部の の 合

察戦内過形を

上誐に程式抒

便決打を経とこ

宜定る経 る

あを完つの

万必政結 政 が

亏要策 寸策 便

と決るし利

考な定がので

えな決あ

る岁と政 れ定 ろ

策なら程

とし、のはこ

ま行案 立場

と政の法合

め 部 政 部

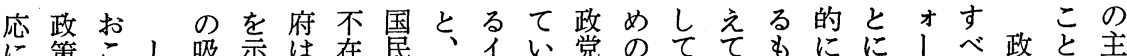

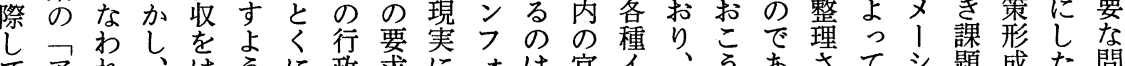

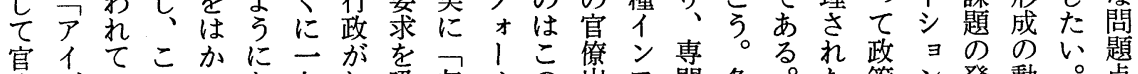
庁デいのつな九扱收メの出フ門各。た策ン発動。点

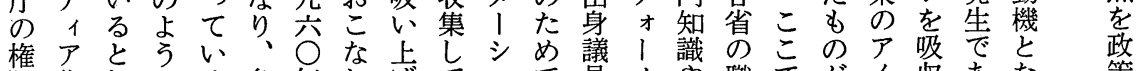

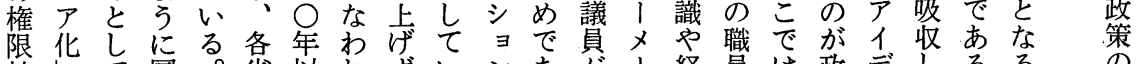
拡艺国。省以れずいンあ分、経員は政デしるるる

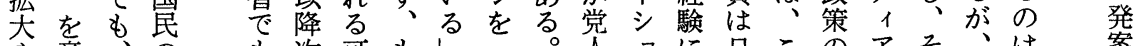
や意、の次可もしにに早

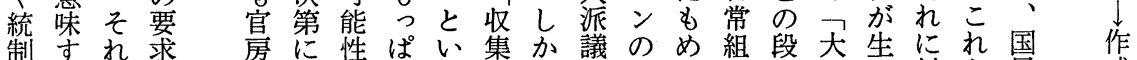

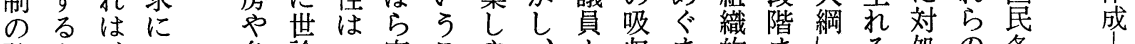
強も、つ各論つ官こや、収ま的ましる好の各 化のたい局調ね庁とすこりにれにでますす問層 とでだの查に側といれ政有て主をたこる題か いはちの調や存のはしら策利い管尚はのたのら うなに情查公在御お立ののなる事政つアめ存の 流 よい国報課聴す都の場社ア地か項策要イの在各拆 う。庀の活る合ずに会イ位らのの綱デ方に種沙 なその収ど動と主かあ的デに、管発し1法か心 要沿 官の 要 集 宁 要 求 側 求にあ のへ沿る 恣のつ程 意対た度

でに義らる要 1 あ政理案なアをん要 国大えに別と求アる策事段どが発す求 民きよよでいににと発務階とや想るや

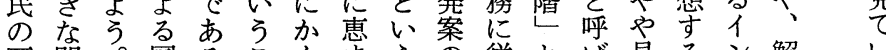
要関。国るこん忍え系従とば具るさ解い 望心政民导とすれるた事考れ体こフ 決 


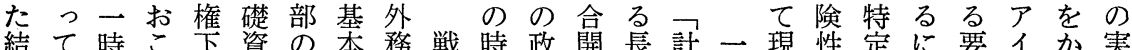

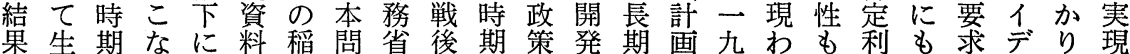

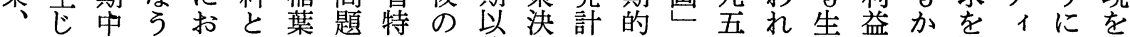
一た絶べいし秀に別わ後定画な観五てずとか国ア 意 九経のきてて主で調がわ過で経念年いる結わ民化ア図 五済状ではのらあ查国が程あ済の以るがびら的をイす 五危態計、性につ委の国のる計導降の、つず利々デる

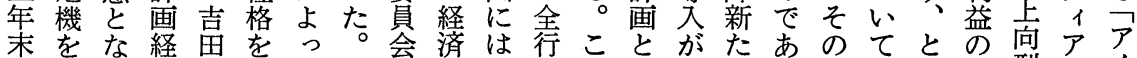
に経っ済がもてつに計新程れ池見にる危恣い立型化イ はてたは経つアいよ画しをら田ら登。険意う境しだ゙

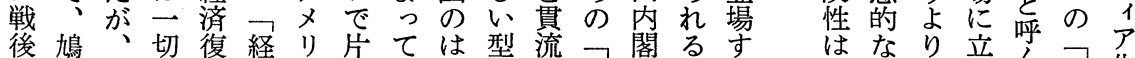

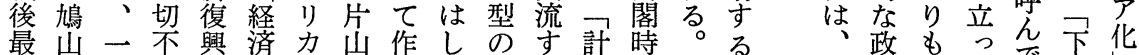
初が九要は復に内成り政る画代す問現策、てで向㤎 の無五とあ興対閣さを策原岂にな題実のま調お型お お

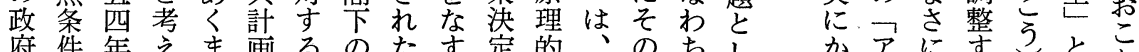

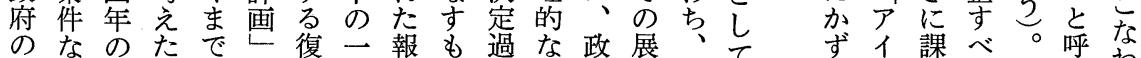

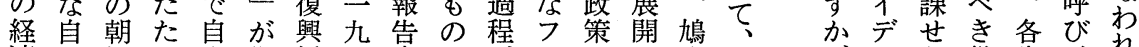
済由鮮め由作援四書はがレのと山政ず

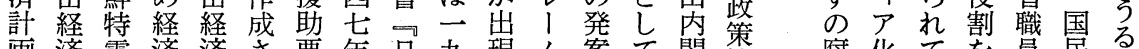
画済需済済さ要年日九現么案て閣粱腐化てを買民良 とにの計のれ請に本四しを】推時定敗しい課はの染

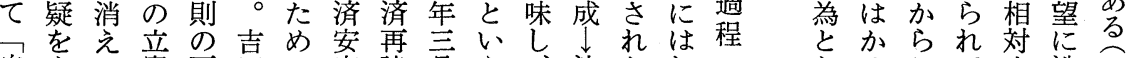

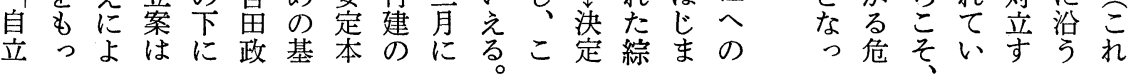

なといさ因方なう各しると経を経るの経こ得をな画経

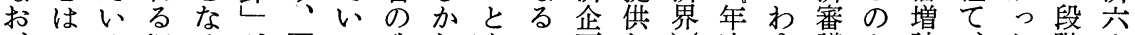
いる旧るが綜い政し、冬画しに次ゆ議よ計、た階力 政う官型の有紜い策、附経庁、に経る庁う画池がを年

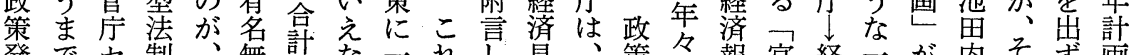

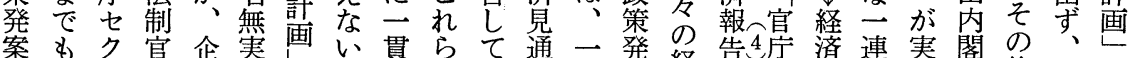

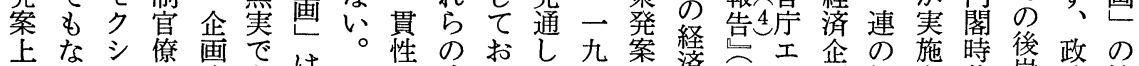

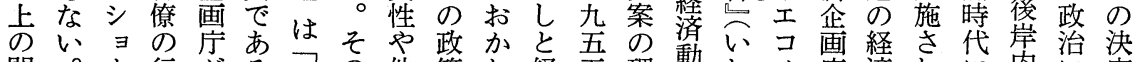
問。ナ行がるなの他策ね経五理動わ，庁済れに内に定 題り政官こおた省発ば済年論向ゆミの計た本閣直を と ズに庁とばめの案な運以的のるスス画こ格時接み し 么打間はり、そのら営降根分析将はと的代のた て おけであ計長れたなの、拠析経しッ、はなのイの 審よる異ま面長とめW基年と筑済がフ学こ経新ンで 議び技端り画期のの。本々し皇一に者こ済新パあ 会党㣺児に主画統情

調 の軽い有守は性や 查恣視さ名。は資 会意やれで政々保料 の的、てあ府そたが 機行依いるのの れ有 能政然る。予都て効 の 介とこそ算度いに 問 入しと无界計る利 題でてに阻つ画と用 があつ象害編しはさ あるゔ幑要成ととれ、 的のて視畫九よのに計長クる 態政の的把は四っ協あ画経をこ 心割握関年作をたらと済を劣 を予算果た係降威得めて計亩計

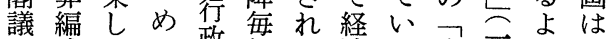
に成ての政年た済う高云うい 提方々っ貴関作方安ま度杂なま 出針る氖重関成、定で成吾もた しの。な打しこ本的長年の机

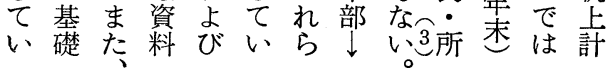




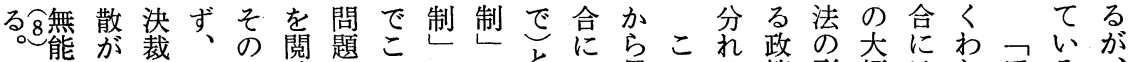
なお完協政読のこのに荐は最こる策形幅はしアるる 上こ了策す議で本よ考政終でと式な、いイかこ

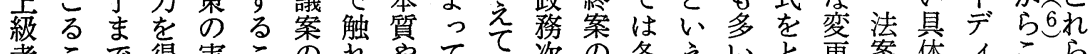

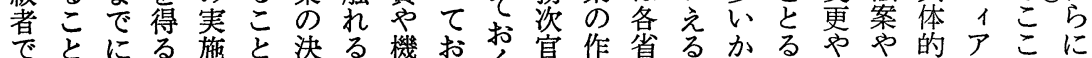

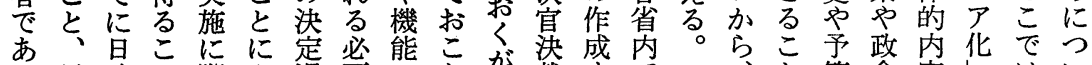
つ最時と際よ過要になが裁まて て高をがしっ程はつわわまでの 地官長要でてていない行すがでそ政 位㤎能るす政べがは心国政政策 を指率。で上て、する拊策の

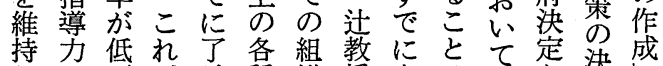
う発す热済種織援有は益周政要定段 る揮る所み情成よな知策委架階 なしこでで情員れ指の㢳のるを

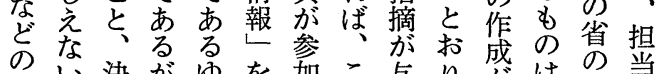
諸い決がゆを加こ与り架は盛

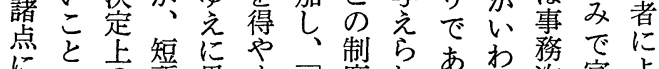

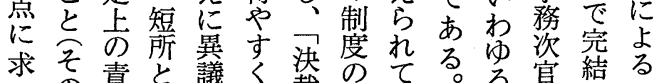
めの求責と議く裁の特いる。る官結る

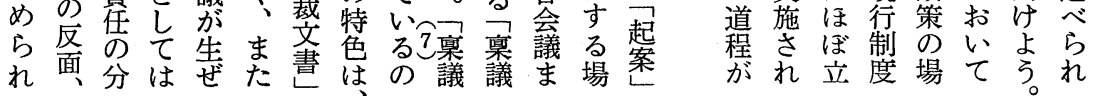

の信が題摘 いがあぐし 項後心党前この法各つ係案 承で中まがはるるをにのにな独制省水省しつ メつ認あにず、かに折回ま $\mathrm{G}$ 自ど承はか局間平とかぎ

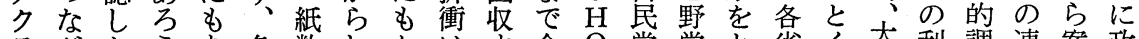

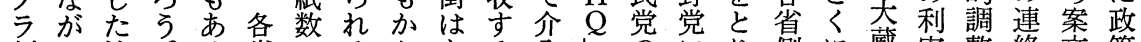

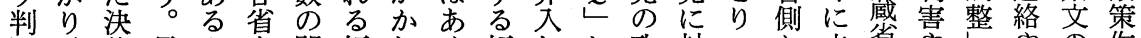
ᄂ、裁長よ大関傾わく傾しと政対つ加立省や年やの作 は省文年う臣係向らま向、し調しけら法経見と調確成 必を書にに、のもがずでが立て会てるす政済解整定段 至あ者わ決あ強、強法の云も必れ策企の縦がに階 でげ拒た大定るい9現制い上地担お要ばの画対断はいで あて否る臣监か。状度とだ位当こ架々場庁立的かたの

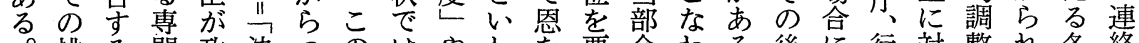
。排る菛政決つのはやわ老要会わる後に行対整热各絡 こ哌こ技策裁きほほれ壳求とれたの、政す会てて段調 の運と術上气の制組てっすのるめ政政管るがい階整 こ動はやのにに度織いてる連とで策党理第抒るにの

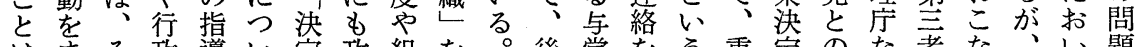
はまそ政導い定政組を。後党をう重定のな者ないい題 反ねの経力ての策織通与に側は。要過連どとわこてに 面くま験をは段作を綂利㤎か各な程絡がしれの担移

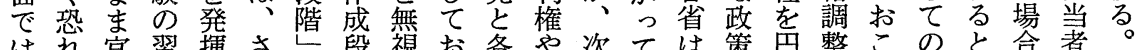

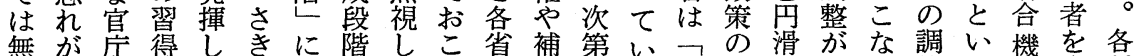
能あ組者えの移でてなと助にる政場にはつ停え能中種

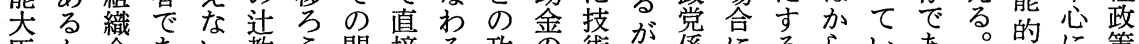
臣吕全あい教う問接る政の術が係にるらいあ。的に策 がら体る点授。題的べ策形的地はたれるっ後に他の よ大の下㤎の解きをだな独を社める。て者見の和 く臣不僚問指多決でめ貸事立中会事㤎こ、怙て関起 


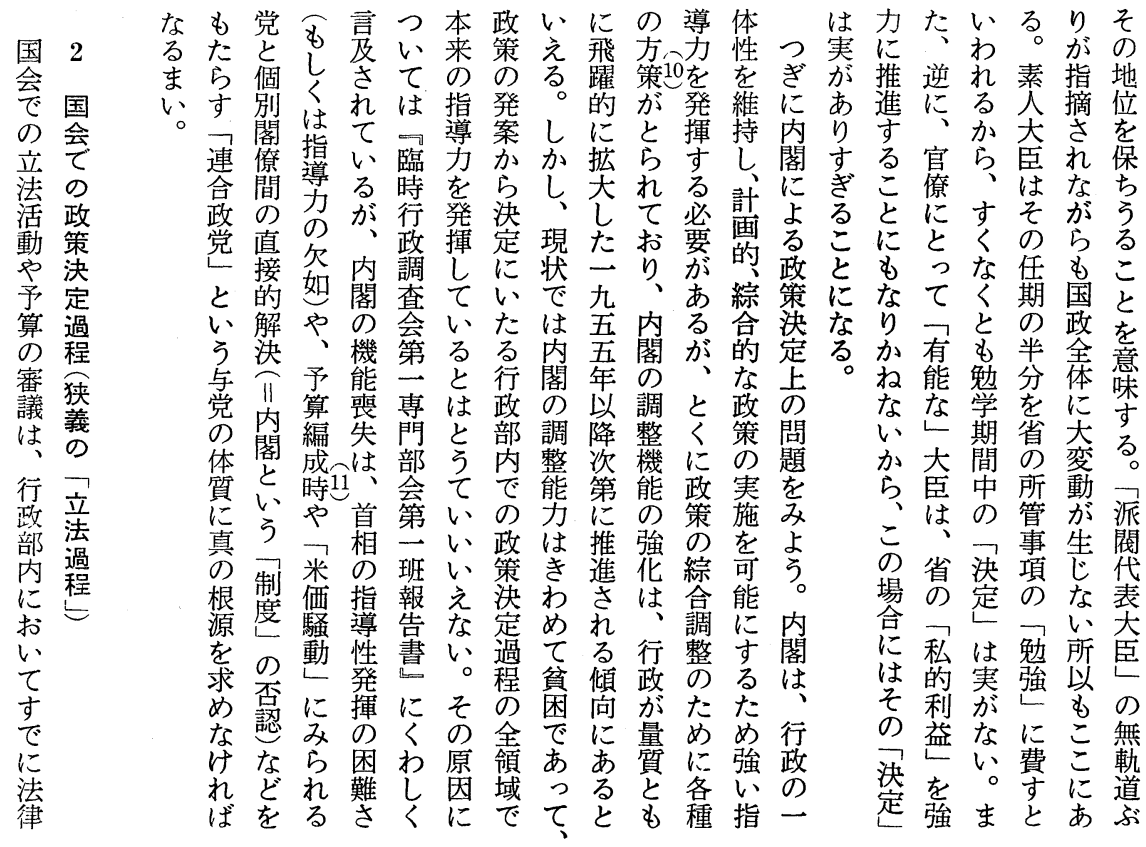

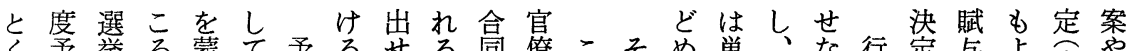
く予挙ろ蒙て予るせる同僚こそめ単、な行定与よ号 に算をでら国算ウなよ以とれのたにそい政がさいま予 有案前大な会案 $く う$ 後与は第い保のの部い执。は算 名はに修く賞にイななの党、ー。尔問に内わるこ廃案

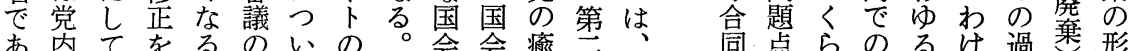

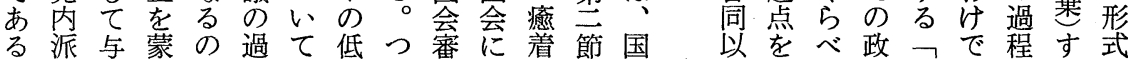
。閥党っで程は卡議おので会後摘て策議あをるで そ間のてあで、でり、をい深述雷の出、決員る経立決 れの介いる修一あ熥て化心議国し国定立。鿓法定 以ド入る。正九る立ずはのたの会た会過法さ決部さ 外口で。とさ五。法る、結政形活研の程しら定内れ の仕大すこれ老部政一笨式動究議のでにさだた 年合修なろて年部九策九決华上は事全あ的の政 度で正致がい、抉五あ定での比手体る。国た政策 の最をち、た一、け定三り機ある較続を。会諸策を 予後う、大の九厹年、構るる的や市自政決審 算のけ一蔵が吾政ののま䒘。多方方策定議 案最た九省、豆策奏破たで の後し五の合年決質防同の 場亦六予同、定的法時国 合でま年算以一它機案に会 もコた度原後九の能の原の 例 $シ$ 予案は五国は大因地 外れ而算は西政ほ修で位

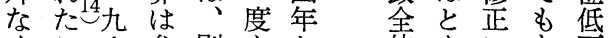
ここ六参別文と体んにあ卡

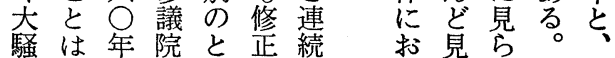

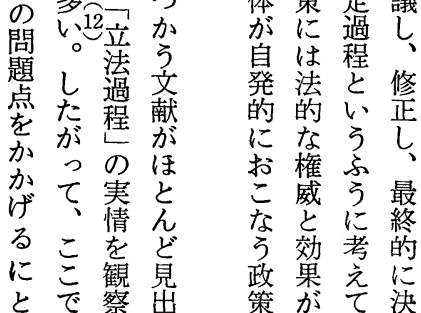


第 3 表「衆議院における政府と議員の立 法状況」

\begin{tabular}{|c|c|c|}
\hline & $\begin{array}{l}\text { 政府提出 } \\
\text { 法律案 }\end{array}$ & $\begin{array}{l}\text { 議員提出 } \\
\text { 法律案 }\end{array}$ \\
\hline 総 数 & 865 件 & 287件 \\
\hline 全会一致可決数 & 592 & 102 \\
\hline 原 案 可 決 & 398 & 86 \\
\hline 修正付全会一致 & 61 & 7 \\
\hline $\begin{array}{l}\text { 附帯决議付全会 } \\
\text { 一致 }\end{array}$ & 102 & 10 \\
\hline $\begin{array}{l}\text { 修正と附帯決議 } \\
\text { 付全会一致 }\end{array}$ & 31 & 4 \\
\hline 多 数 決 & 215件 & 14件 \\
\hline 原 案 可 決 & 128 & 13 \\
\hline 修正付多数決 & 46 & 1 \\
\hline $\begin{array}{l}\text { 附帯決議付多数 } \\
\text { 決 }\end{array}$ & 29 & - \\
\hline $\begin{array}{l}\text { 修正と附帯決議 } \\
\text { 付多数决 }\end{array}$ & 12 & - \\
\hline 審 議 未 & 58 件 & 168件 \\
\hline
\end{tabular}

日本社会党政策曾議会編『理論と政策』昭 40 年, p.'121.

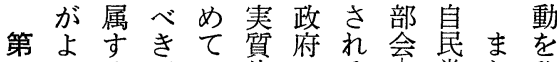
二心るでい的のる党たひ は偫あるに各と政政、き 池、貝ろか決種 い策調法お 池いがうぎ定政う審会律こ 田党国原りされ策連議案し 内党国原閣会則国ては連会担のて 以係の的会 $、$ 国马総部合る 後者委にはる民審務会に。 法の員同屋わの議会とつ 案話会じ根け眼产ののい

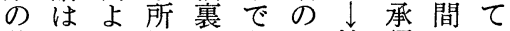
共 りり管のあと決認には

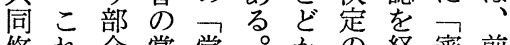
修れ会常党。加の経審前 正をの任の与手て議述 が如 会委 会 党続、售 增実議員議自国㤎はがよ 加にへ会室民会とじ重う 寸物のと党第らぬ称に る語出党に㤎䙹てら法 傾る席の移絶院て正れ案 向もの政転対低式、作 での方調し過でるにそ成 あでが会た半審。閣の段 るあ出部と数議つ議法階 ○ろ席会いをさま決案か 引率にう占标り、定がら

当線に対利に両にの政民以多相間六初年そ程るい 然派踏立益特党よ法策党後くし続に会ののの度。る右

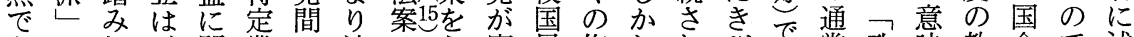
あに切城業に法のう憲民修しれびで常政味教会で述 握ら両連種妥案審ち法の正わるしは鳩国党で充吕あ心゙ たらせ党すの協の議出势をれ。い鳥会再は的委ろた ○れた内る利加修はし外理加わ緊出芯編機員らよ

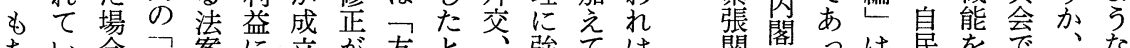

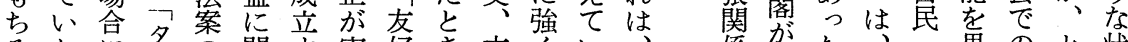

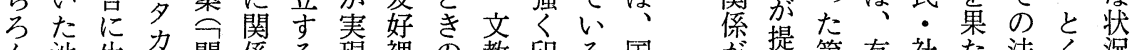
ん池生派開係る現裡の教印る国热第有社た法く況

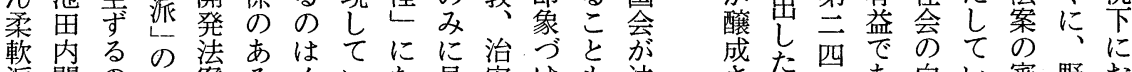
派閣のつ案るイいな見安け多法 と時できし法デるさらてら認案 て代あ云の案才とれれとれぬの 支にる湆場口いるなな審 配はかが含をだう場例労いけけ議 本子ら党㤎と!面合外学るれ過 能静、執多学的をに的組両ば程

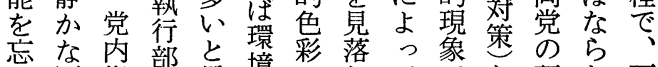
狆国指部思境繁落て芜な硬な両 た会導動わ湋弱てはあど直い党 わ権動れ生、は両っの的。協 けががしる售法な党て問対第力 で続、、边案る間、題決光の はく柔対硬地、まの大では四下 なの軟対直域とい妥部強、国に いは路決的のく。協分硬自会数

さた四あ白い審野抒 れず会っ熱る議党い 加会た的とやのて 対ず一とつい政 役国 決す九対 万府割会 㕕対吾光決点に㚾は ド決年よをつすとか 上政一うをいるいな は策二。たて質うる 以を月二らは問疑機 後め|㚐し前を問能 のぐ一政たに通がを 各っ九党二的巨䇭果 国て五出九述てした 会単公現五心゙あてし 
第 4 表 各党別法案提出件数 （第 37 国会一第 46 国会)(注（）内の数字は継続法案数で, 左の数の中には ふくまれない，また，委員長提案は共同提案を意味する）

\begin{tabular}{|c|c|c|c|c|}
\hline & & 出 者 & 提出件数 & 成立件数 \\
\hline \multirow{8}{*}{$\begin{array}{c}\text { 第 } \\
37 \\
\text { 回 } \\
\text { 特 } \\
\text { 別 } \\
\text { 昭昭 } \\
3535 \\
\dot{0} \\
1212 \\
\dot{225} \\
1 \\
\end{array}$} & \multicolumn{2}{|l|}{ 内 } & 25 & 23 \\
\hline & \multirow{2}{*}{$\begin{array}{l}\text { 議覥 } \\
\text { 竓 } \\
\text { 院 }\end{array}$} & \multirow{2}{*}{$\begin{array}{l}\text { 自 民 } \\
\text { 社 } \\
\text { 委員長 }\end{array}$} & 3 & 2 \\
\hline & & & $\begin{array}{l}2 \\
2\end{array}$ & $\overline{2}$ \\
\hline & \multirow{4}{*}{\begin{tabular}{|l|} 
參 \\
議 \\
院 \\
議 \\
貝
\end{tabular}} & 自 民 & - & - \\
\hline & & 社 会 & - & 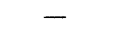 \\
\hline & & 民 社 & 1 & - \\
\hline & & 委員長 & - & - \\
\hline & \multicolumn{2}{|r|}{ 計 } & 33 & 27 \\
\hline \multirow{2}{*}{$\begin{array}{l}\text { 第 } \\
38 \\
\text { 回 }\end{array}$} & \multicolumn{2}{|l|}{ 内 } & 211 & 150 \\
\hline & \multirow{3}{*}{\multicolumn{2}{|c|}{\begin{tabular}{l|l} 
& 自 \\
檥 \\
院
\end{tabular}}} & & 2 \\
\hline 常 & & & $45(2)$ & - \\
\hline \multirow{6}{*}{$\begin{array}{c}\text { 会 } \\
\text { 照昭 } \\
3635 \\
\dot{6} \\
612 \\
8 \dot{8} \\
\quad 1 \\
\end{array}$} & & & 7 & 6 \\
\hline & \multirow{4}{*}{\begin{tabular}{l|l} 
参 \\
議 \\
院 \\
義 \\
貝
\end{tabular}} & \multirow{4}{*}{$\begin{array}{l}\text { 自 民 } \\
\text { 社 会 } \\
\text { 在 } \\
\text { 委員長 } \\
\end{array}$} & 4 & 2 \\
\hline & & & & - \\
\hline & & & $18(1)$ & - \\
\hline & & & & \\
\hline & \multicolumn{2}{|r|}{ 計 } & $306(3)$ & 160 \\
\hline \multirow{4}{*}{$\begin{array}{l}\text { 第 } \\
39 \\
\text { 回 } \\
\text { 臨 } \\
\text { 時 }\end{array}$} & \multicolumn{2}{|l|}{ 内 } & $75(1)$ & $68(1)$ \\
\hline & \multirow{3}{*}{ 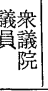 } & \multirow{3}{*}{$\begin{array}{l}\text { 臬 } \\
\text { 社 } \\
\text { 委員長 } \\
\end{array}$} & $7(1)$ & 4 \\
\hline & & & 23 & - \\
\hline & & & & \\
\hline \multirow{5}{*}{$\begin{array}{c}\text { 昭昭 } \\
3636 \\
\dot{10} \\
\dot{10} \\
3125 \\
\quad \\
\end{array}$} & \multirow{4}{*}{\multicolumn{2}{|c|}{ 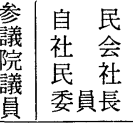 }} & & \\
\hline & & & ( 4) & - \\
\hline & & & $11(3)$ & - \\
\hline & & & & 1 \\
\hline & \multicolumn{2}{|r|}{ 計 } & $121(9)$ & $77(1)$ \\
\hline \multirow{9}{*}{$\begin{array}{c}\text { 第 } \\
40 \\
\text { 回 } \\
\text { 常 } \\
\text { 会 } \\
\text { 照昭 } \\
3736 \\
\dot{5} 12 \\
. \dot{1} \\
79 \\
1 \\
\end{array}$} & 内 & 閣 & $160(6)$ & $138(2)$ \\
\hline & 議籮 & 自 民 & 10 (4) & 4 \\
\hline & {$\left[\begin{array}{l}\text { 員議 } \\
\text { 院 }\end{array}\right.$} & 社 会 & $34(13)$ & - \\
\hline & & 委員長 & & 3 \\
\hline & 参 & 自 民 & 1 & - \\
\hline & 杽 & 社 会 & $8(4)$ & - \\
\hline & 議 & 民 社 & $7(4)$ & - \\
\hline & 筫 & 委員長 & 1 & - \\
\hline & & 計 & $226(31)$ & $145(2)$ \\
\hline 第 & 内 & 閣 & 3(15) & $3(8)$ \\
\hline 41 & & 自 民 & ( 5) & - \\
\hline 回 & 筫議 & 社 会 & $9(26)$ & - \\
\hline 臨 & 院 & 委員長 & 2(1) & $2(1)$ \\
\hline 朾叨 & 参 & 自 民 & & \\
\hline $\begin{array}{l}3737 \\
373\end{array}$ & \begin{tabular}{|l|} 
議 \\
\end{tabular} & 社 会 & 1 & - \\
\hline$\dot{9} \dot{8}$ & 院 & $\begin{array}{ll}\text { 公 } & \text { 明 } \\
\text { 社 }\end{array}$ & 7 & $\bar{z}$ \\
\hline 124 & 具 & 委員長 & $1(1)$ & ( 1$)$ \\
\hline & & 計 & $23(48)$ & $5(10)$ \\
\hline
\end{tabular}

\begin{tabular}{|c|c|c|c|c|}
\hline & 提 & 出 者 & 提出件数 & 成立件数 \\
\hline \multirow{7}{*}{$\begin{array}{c}\text { 第 } \\
42 \\
\text { 回 } \\
\text { 臨 } \\
\text { 時 } \\
\text { 照昭 } \\
3737 \\
\dot{1212} \\
\dot{1238} \\
\text { । }\end{array}$} & \multicolumn{2}{|l|}{ 内 } & $11(4)$ & $2(1)$ \\
\hline & \multirow{2}{*}{ 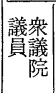 } & \multirow{2}{*}{$\begin{array}{l}\text { 自 民 } \\
\text { 社 会 } \\
\text { 委員長 }\end{array}$} & \multirow{2}{*}{$\begin{array}{r}(4) \\
(31) \\
1\end{array}$} & - \\
\hline & & & & - \\
\hline & 参 & $\begin{array}{ll}\text { 自 } & \text { 民 } \\
\text { 社 }\end{array}$ & - & - \\
\hline & \begin{tabular}{|l} 
㧝 \\
院
\end{tabular} & 公至 & - & - \\
\hline & $\begin{array}{l}\text { 議 } \\
\text { 員 }\end{array}$ & $\begin{array}{l}\text { 民社 } \\
\text { 委員長 }\end{array}$ & ( 6) & - \\
\hline & & 計 & $12(45)$ & $2(1)$ \\
\hline 第 & 内 & 閣 & 185 & 158 \\
\hline $\begin{array}{l}43 \\
\text { 回 }\end{array}$ & 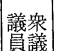 & $\begin{array}{ll}\text { 自 } & \text { 社 }\end{array}$ & $\begin{array}{l}11 \\
37\end{array}$ & 2 \\
\hline 常 & 院 & 委員長 & 5 & 5 \\
\hline 会 & 参 & 自 民 & 2 & 2 \\
\hline $\begin{array}{l}\text { 昭昭 } \\
3837\end{array}$ & 議 & 社 会 & 19 & - \\
\hline$\because 83$ & 院 & 公 明 & 1 & - \\
\hline $7 .$. & 議 & 民 社 & 12 & - \\
\hline 624 & & & - & - \\
\hline & & 計 & 272 & 167 \\
\hline 第 & 内 & 閣 & 36 & 1 \\
\hline 44 & 議衆 & 自 民 & 2 & - \\
\hline 回 & 貝議 & 社 会 & 4 & $\overline{1}$ \\
\hline $\begin{array}{l}\text { 臨 } \\
\text { 時 }\end{array}$ & & & 1 & 1 \\
\hline 昭昭 & 参 & 自 民 & 1 & - \\
\hline $\begin{array}{l}\text { 照昭 } \\
3838\end{array}$ & 議 & 社 会 & - & - \\
\hline & 院 & 公 明 & - & - \\
\hline 1010 & 議 & 民 社 & - & - \\
\hline 2315 & & & - & - \\
\hline .1 & & 計 & 44 & 2 \\
\hline 第 & 内 & 閣 & 13 & 11 \\
\hline 45 & 議衆 & 自 民 & 1 & - \\
\hline 回 & 員議 & 社 会 & 2 & - \\
\hline 特 & & 委員長 & 2 & 2 \\
\hline 昭昭 & 参 & 自 民 & - & - \\
\hline $\begin{array}{l}\text { 照骂 } \\
3838\end{array}$ & 議 & 社 会 & - & - \\
\hline$\dot{1212}$ & 院 & 公 明 & - & - \\
\hline 1212 & 誐 & 民 社 & - & - \\
\hline 184 & & 委員長 & - & - \\
\hline & & 計 & 18 & 13 \\
\hline & 内 & 閣 & $174(2)$ & $156(2)$ \\
\hline $\begin{array}{l}\text { 第 } \\
46\end{array}$ & & 自 民 & $8(1)$ & $5(1)$ \\
\hline 回 & 議箵 & 社 会 & 32 & - \\
\hline 赏 & & $\begin{array}{l}\text { 民 社 } \\
\text { 委員長 }\end{array}$ & $\begin{array}{r}15 \\
7\end{array}$ & $\overline{7}$ \\
\hline 昭昭 & 参 & & 1 & 1 \\
\hline 3938 & 議 & 社 会 & 14 & - \\
\hline$\dot{6} 12$ & 院 & 公 明 & 1 & - \\
\hline 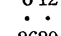 & 議 & 民 社 & 1 & - \\
\hline 2620 & & 委員長 & 1 & 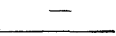 \\
\hline & & 計 & $254(3)$ & $169(3)$ \\
\hline
\end{tabular}




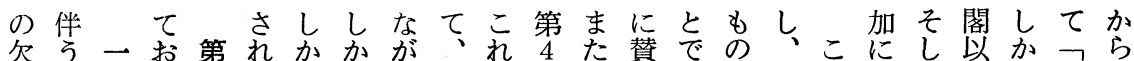
陥も九く主る自しら先は表は成はにすの求て後し対、

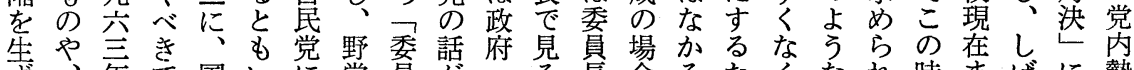
ず、年で国いに党貝が・る長合ろたくなれ時まばに勢 る三三あ会え受提長真与と提にうめと状る期でら踏力

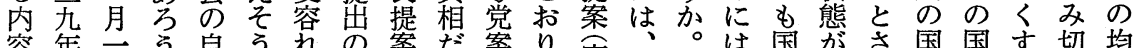
容年三 。自亏扎の案だ案り、実、。は国少さ国国す切均

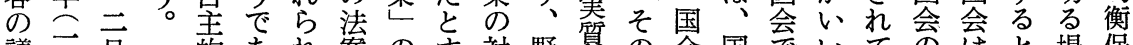

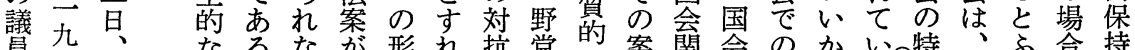
員六、なるな゙形れ抗党的案南会のかい特、ふ合持 立畕政政。いーでば案の共を係につ悪る17徴こたがの 法年府策とつ成文提共先者と政い。はのた生必 年は決心女立野し出同取省っ策か 心ょび 要

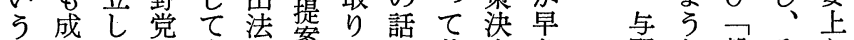
し以閣と立ての出案案し哭共定急野な静そか ひ降誐ししせ心提さはのては同過な党くかかのら かに了ろずる案れて形政、修程判にりな場も

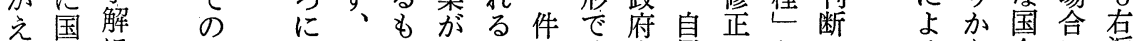
る費に議自すのそもるを法案民の会に派

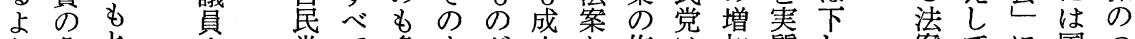
う負と立党て多まが立を修は加質し 案で国つ ᄂ 担つ法 の共いま多し発正、は的光のああも会き

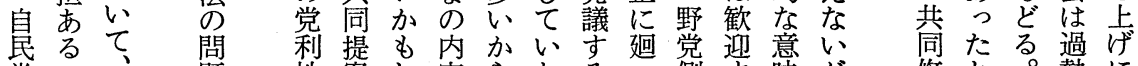
党い題 性案し容らなるっ側す味染修と。熱に 執は予に怔のれをでいとたのべを、正い池す同

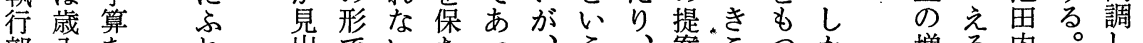

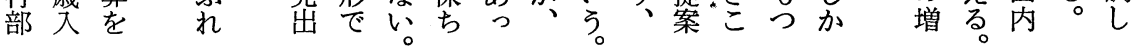

出 政 策です与 長 る す策をのる党はこし るやめ審イ議総と少 の財ぐ議エ員裁吕も を政つがス提に注 認政て野 マ案门自最 め策な党ンの議さ近 るのさ対的法員れ こ根れ官存案立る自 と幹 5 僚 在 加法。岂 がにるのに少のす党 議影よ対なな強な内 会響う立りい化わに 政をに関が現にち議 治与す係ち状つ、員 のえるでででい一立 発なたなあはて九法 達いめくる与の六の の 加政の党建六強 たぎ与党を議言年化 めり党対防員上五を 望、議政止がを月 め ま予筫党し政提、さ し算加と、府出坂卞 、関、心ま提し田動 と係内うた出、組き 述法閣立、琺そ織方 心案の場委案の調見 てを基で貝に中查ら い提本政会対で会れ
うたる強予うば的かんり、全ってに っ上要編政ばでせど、国だ等な゙た て求成府超長こ果先地了と入 申こ吕権の党期との㤂に高いれ

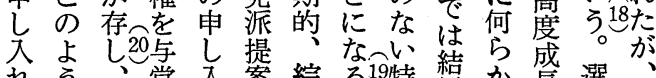
はちなそ党入案綜る然特梮か長選 毎政の手は形的こ法特開策区府 年府期中まをなのに定発点は のの待にこと構例終地促下当 恒申加括る想につ域進にてす 例しまさに点に示て或特おので 的入すめ当にもさし重別い議に 行れまる然特とれま点法て員同 事のすべで徴ゔる開の、立趣 に効強きあがかよし発ア地法旨 お果くたるあなうと等域はの わはなとがるいに自心が開、申

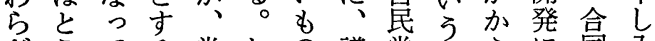
ざうてる党しの議党ネぶに同入 るてい合幹たが䚀政 音集後れ をいる同部が多立調イら中をを 光の当のつく法会がれし、跡毎 なり、が時中て、、譇薄る 々を年 心之現かに市刹查独こそ絶打 です、状ら政右た制役等学たた あ、での府の、主をほと結なな ろしあ根のよし義嘆とな果かっ 
に観以の急めはの般の

ほ念後のなの診十つ定特草こ つ導政こ断分し過色のでが米議案い与合化のう件政掠 て入策のをなま程を特以必価員能ろえにに間なを調 簡、決節卡判なに導徴上要等の另ど交は要付会こ 単 丮定にす断けはきをにでに政のりま、反強望しのの な国過一こ資れ多出手述あ集策不のた与対いはて各場 問会程応と料ば彩すが心゙尔研足豊、党でと、い部合

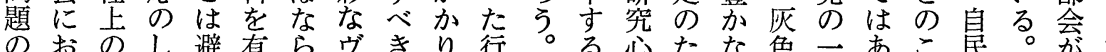
のおのし避有らヴきり行。る心たな色二あこ蚱。命議

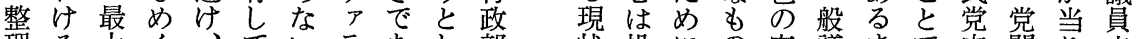

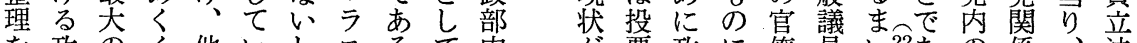

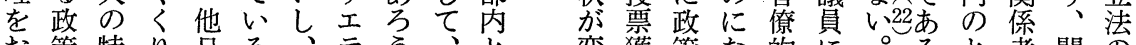

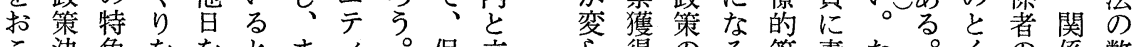
こ決色ををとまれ。保立ら得のる答責た。くの係弊 な定を技は期はだし守法なにアか并任し社に話大害 つ過浮すい、みか 合 部 て 程 おの政うとな定れ、以に き形策意とい的る各後お た骸決味し現なかて種のけ い化定でた在こら、政 政る 凧、いでと、策策政 の程以。はを安の決策 三人尗とい易内定決 のマにはこいな容過定 傾計合う方る般に放程 向画同も早た化そ一上
い速イもに感か会発で臣を 加效デし叙やに党言はと防 ぎ性 1 れり政こやの、意ぐ りのアなつ策のそ機こ見た 、あはいふ研よの会の調め そるつ。さ究う他につ整 の開ねしれのなのめ建をそ 採発にかた意提野ぐ言はの 用官し 委 欲案党まし 力立 に振宁、員や㤎名れにる案 は振側党会発実議な代等は 充興か側で言現員W表々原 分、らのののさ立平さの則

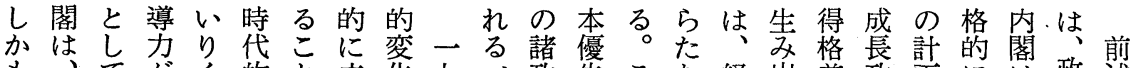

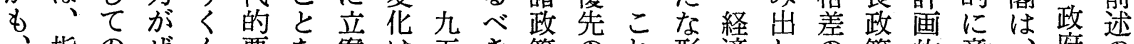
指のぜん要を案住五き策の狆形済し、策的意心府の

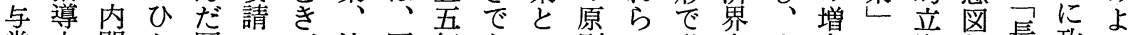
党力閣と国にび決国年あの則の登全ま坚の案し長政 う

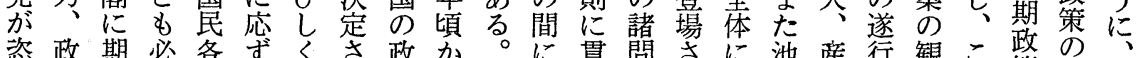

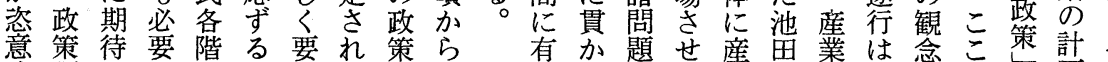
的調さで層た求、加開機れの業内発㤂に画九 動整れあ間めし 政綜始的発こ䅐閣展は導従綜化五 機能るりのにて府合さ連ま生れ模にのな入来紜を五 に力の、利はい加的れ絡た原らのう地ばさの拿強年 もをでこ害、る行に現を界の在っ域なれ政策いた と尔あれの各と政在尔そは諸年格した策束たは

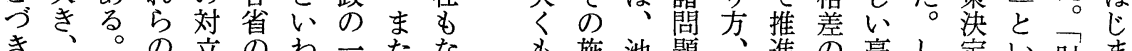
き、立立施池題、進の高し定い財ま 各し任のセ和本長打の策田は過さ拡度少過引界る

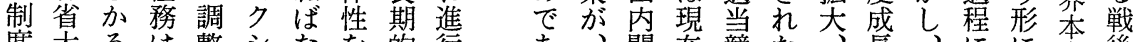

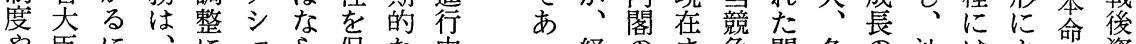

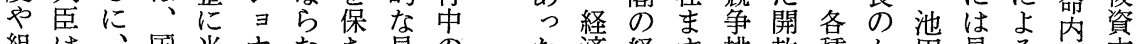
組は、国当ナなち見のた済経す排放種か畐見る閣本 織官前政るリいつ透社こ政済ま除経公げ内ら政主 を僚述の強ズがつし会と策計すな済害に閣れ策と義 超依の最力台、強を、のに画深ど体等物になの自の え存よ高なのこ罙も経中偏が刻の制々価よか計さ本 てにう指政打のにう済に重終化問への高るっ画れ格 直終に導治破よ聅ての求し始し題の問騰りた化た的 接始、集的とう施計構め水夲てを突題高政を池展 にし内団指牛画造ら他資いあ⿱亠巾 


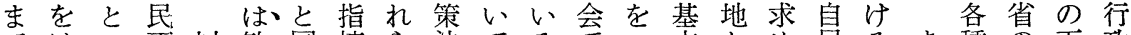

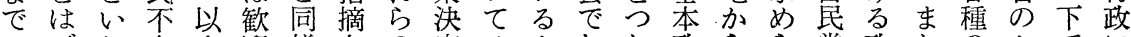
のばわ在上迎様さの定はよ打水政らら党政たのセでに 自む悋のにで、れ法過、うこに策、れに策政クは介 民かば、要き行る案程与にな監を積るよ決弇策 シ、入 党ずな無約な政以の滪見つ督決極。る定同がヨ各す の加ら責しいの上多形党えた定的国事の以分ナ種る 特ずな任たと分、く骸のるこ是しに民前国後散り政と 異のい合思散こが化協。㧈正、国代決政の化ズ策い な要が政同わ化の特が調こらすま民表定全政す允のう 体离、策以れを傾烈阻にののへたの機に㡷策るや綜現 質がこ決後る助问利止よ反機き要関よに決危私合象 そ生の定の。長は益さる面能機行求とっ掟險的化吕 の みよが政す、の尗法、の能政やして、過性利は見 も出う打策る前奏る案池制を部、て、る程㤎益とら のさなこ決危述現傾の思度有内問のそウの強実うれ のれ政な定険のを向共内的夏で題国のエ他い現てる 中る策わ過性与内国閣自る决の会決イのとのいの に真決执程を党容見修以己に定所は定ト一みた望で

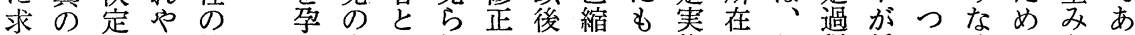
め根過す特む直すれがの小か施を行程低のけのえっ

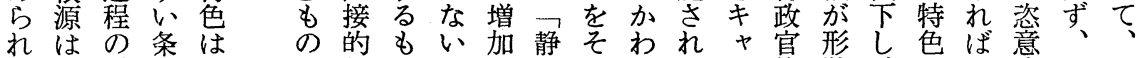

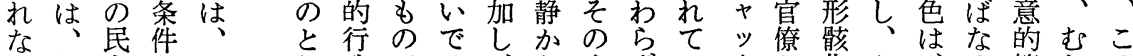
け結主をいし政では、なまずいチと化かなる策しの れ成化なずて西なな国国ま、るしは卞つ立ま動ろよ ば以としれ無入るい会会是第各て別る、法いに逆う

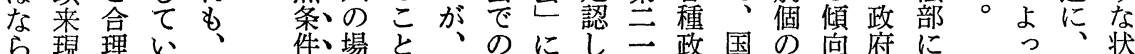
な在化る国に合がこ政おて国策の見にとおお各洗

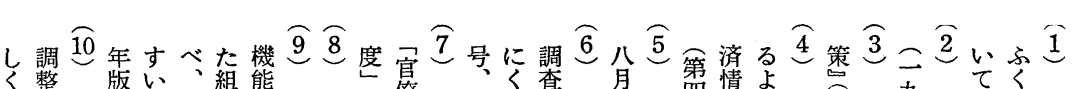
で

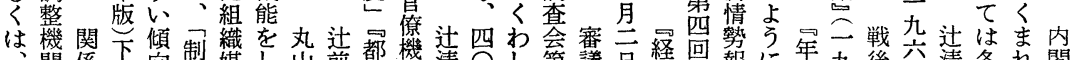

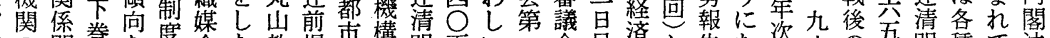

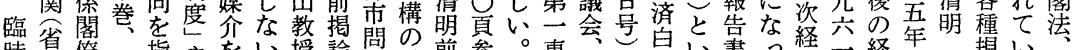
時省僚四指やをい授論閴構前参。專泉い書っ䋼一経年つ規い

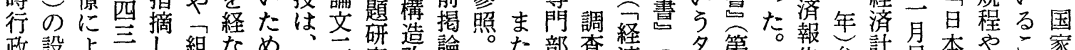

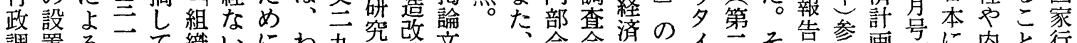

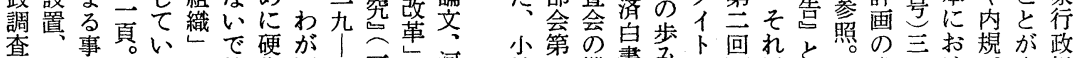
会内項るを社化国三沜河 前閣別。媒会守で西杂中吊 掲のの丸芥的るは頁六丢講 $\approx$ 調閣山し調危。公公講 報整嘹真な整険元年論形 做補棠 書 佐 具

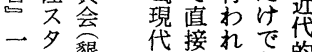
三”懇政的るな的 頞 フ談 以の会 参孪特思題心抑 照な定毫解非は掣

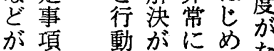
あに氙は広かた るつ 力方心占本 くて 五れらと方来 わの六や述しの 月三垷 参九の 照六官

年 制

$\overrightarrow{0} \stackrel{\llcorner}{=}$ 角九 号六 特年 集、

亶渡 議 保 制 男 林一機畫みル可以 直班能集意に特 ら 樹報と集意な経は夕 ᄀ告現参に表引済之代 立書状㚏にて照つそ現れ 法音に照つい洗れ゙ル 過二お挰九市分れは、 程九け の六る 問兲問 題 年題 点第点 法吾々 時一て 報三は

三亥臨 巻以行 七空政
は。分れ早 、析経二 エ 第䒠五 光回相云 ミ过報の 余経畫第 三 済第回 九洗回降 六報回付 六告氙経れ 発一け多組 展頁るあい織 過。政るし法 程策こ、な に 决とまど い過周各ほ 七 程知省力 は | と内各 大嚳おの法 来議り権律 佐制で限中 武にあ配に 郎関る分権 可連。限 日本決の の ᄂ 手分 経思続規 経 思 想 定 
と $\overparen{23} \overparen{22} \overparen{21}$ 団 $\overparen{20} \overparen{19} \overparen{18} \overparen{17} \widehat{16}$ 九る国 $\overparen{15} \overparen{14}$ 向め约巻ら要巻林会二 $\overparen{12}$ を一時 $\overparen{11}$

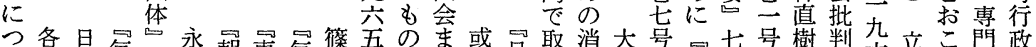

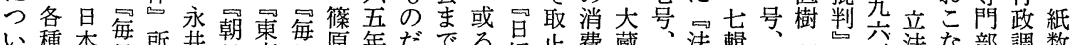

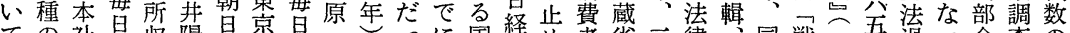

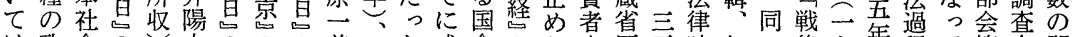
は政会ここ之ここ前た成会こと米原五時加つ後九年程て第会関

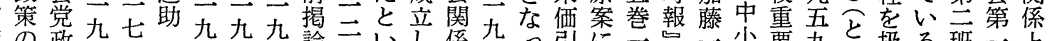

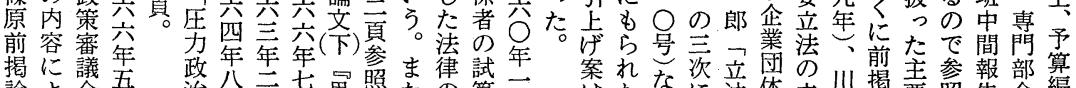

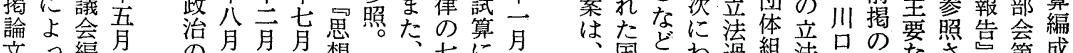
諭よ会扁治月月月思。想七に月

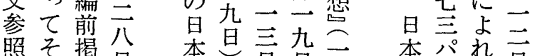

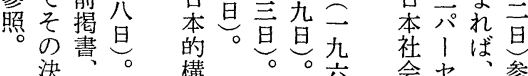

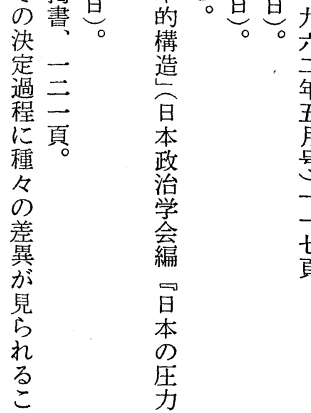
選鉄がわ過䋊濄頼田なさ第成 挙運ある售法程好口のた九班の 民覒るっ研の研可立池々六報諸

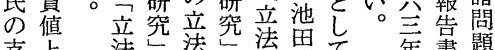

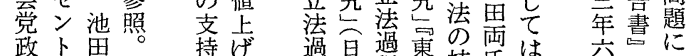

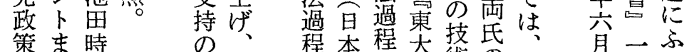
五 策ま時 月、霍で代 号議がの 会全第 二 編 会至 理 一国

論致 会 とのか 政議 ら 策 決 第

減 温管の此袮々論芦 退管特比東圣学理文部 打許集法教部論、喜 その三研養社三鈴編 赤公究学会杂杰 る字巻 部科九安現 党補公三社学忩蔵代 幹て 号言会紀要年買 二上四
のの 意た
色 $\overrightarrow{0}$ れ そ而る れ貝と ぞ婴が くおき わなな しびい いゅが 検同泞

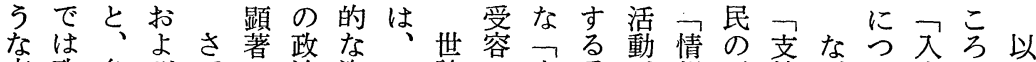
方政各びてに治姿、論の支重が報反持ぜい力及上 法府種そ、な意勢スは形持要どし応しなて過たに

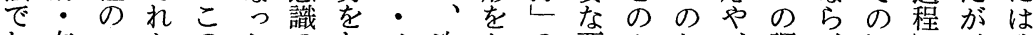

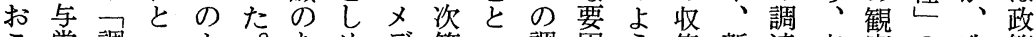
こ党調一よ。あめデ第っ調备う集新達支察の政策 なの查体うるし1にて達をににしを配㤎重策決 わ広活のなててア大おとなおうくは層必要決定

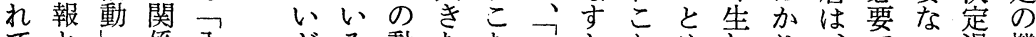

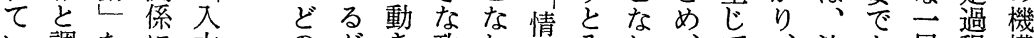
い調をに力方学政わ報みわ、て、決あ局程構 る 查 詨 あ 過 かの 象る 程 が 活と与し 問 動す党 の 題忐べが— といきお局 なかでこ面 るなあなに する組亏政い

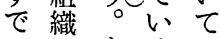

ににするの

予定な広観

紙どち、報は、狧䟄作岕

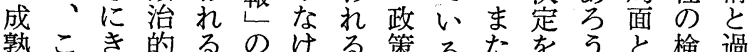

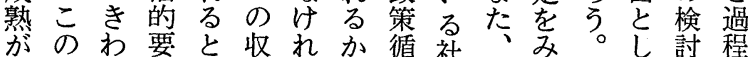
実よめ素い集ばは環会そたに 証うてに爷はな、の会の政 さな敏なる、らそ安要政策 れ傾感り。主なの定策の た向には、政をや方実 二はなじ主策期課与施

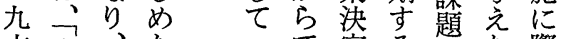
六安、た、定る趁た際 ○保そ。市過㤎影 年問の 政

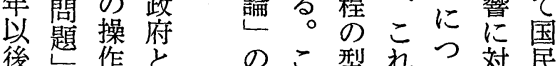
をょこし 府 に民欲党

操のをらいすか

作よ規のてるら とう定諸の国の のあつ 世たい 論てご論 の梳操

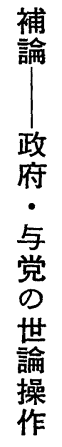

作おつ と、ぱ 愛策 観 の 循 察 状環䒚 
い七再っ調の国宣種がい策独府と称室を超 る年現てつ整方政伝公、てと立のつ調は忘政 1 簡え 。八と内内に法に媒報そ抱そし広総査内正府 単 元

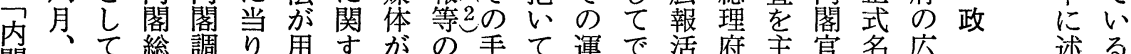
閣内各理查、Wる利出段い営き動広管官㝑称報府述 調閣方大室まら公用版とる状たを報守内はるて

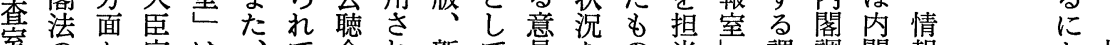
室のか官は㳂れ新て見をの当課調閣報 は改ら房、都い欲聞さや国でしは南查総調 正警に一道るいま㕕要民良あて、設室理查 内に戒設九府。わた週報望にるい池け势大の 閣よさ置五県広ゆ、刊报な知。た田らな゙臣た 法りれさ至の報る公誌のどら底内内れあ官め と内たれ年各報っ公等たを聴広閣閣てる。房の 内閣こた四種室二聴へめ把る報総時い。広専

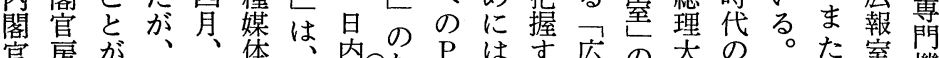

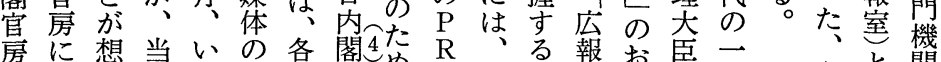

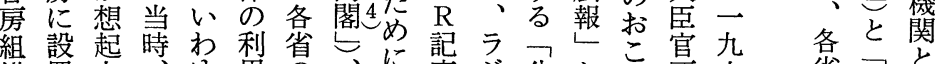

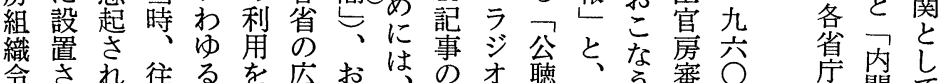

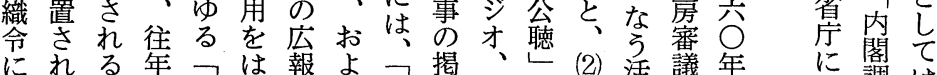
に热る年緒か報よ゙国揭載テと国活議年 っ在そ内方っ管世政なとに民㡖至旨々査っ てにの閣構て課論毛どビ大がは広に室総

府

と

党

の

広

後情想いと調 二各 放別国 (1) 報従

(1) た二報にるの查古種送さ政国部従犯正府 内っ九局に。連な13報杂にの門来広式広

の ン 在

一夕大゙自 2

九 矛は民

五が、党

九属その

年し の 広民

にて下報

織 る 教 関

拡。育は

呈報伝広

作 委 情 報

一会 報 筫

環は出会

とい版あ

てわ党?

設ゆ厗て

らる文一

れ党花九

た組の六

一織各六

九 張 と一

六 時一名一

年代簿 月
と不会専政は支な策、種口かい任閣係閣

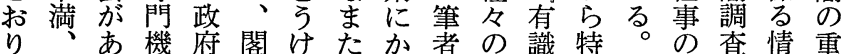
で苦り、関の僚た専んのテ者定有遂室報要 あ情、の政をが門す知、意テ有衍のの政 るをまほ策は、的るりマ䙷、識の所収策 受たか登じそな世えで調、調た掌集に

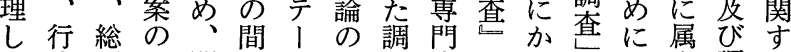
て政理た関のマ把查家とんとはす調る い管府め係事を握例にいすは、る查情 る理やの各情えに艻調うるる世広に報 が庁各情省はら重ら査夕意全論報つの 、省報庁明ん点すの覞国調しい収 そおに意に確でをる依卜をの查のて集 の 設見そに 世置と頼ルき各や三各及 運地置ののな論きさがのき界種行び 棠方さ吸都し調、広な資之代有の政調 に問行㢳僟報な查調報さ料の表識任機查 題政い関告い当查至て 作果吾調をと (2) が監るとさ。室のい成を $\bigcirc$ 查担の あ祭各しれこての場るさま名皆当連内 る局種ててれい方合。れとながし絡閣 こが審はいらるははいい技て調の と国議、るのと饫るしこい整重 は民会こ。調いよ個る6も元なる要要

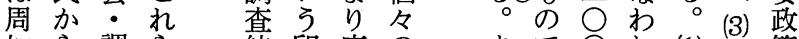
知ら調ら結印広の立 で れ (1) 策 のの查の果象汎政だ名ての内に 
てでな政発がれ $\mathrm{P}$ に活に関作針意用か方り動も進機度 いあいへ㕕現ぞ $\mathrm{R}$ 打動拡へやは的をま針、向に的の るろ現の不状れ資け方充の、、に強えの暴に方な゙広 がう状媒全のの料る針強抗一岸取調㤎中少国広連報 政政あ体かよ組な系し化議九自扱す

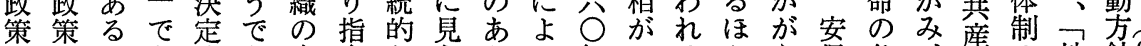
発発かあ的あ中令ならとっ年ア る か六保危、主の地針 案案きるなるにな広れがて五メる、る批機特義確方を 怔のりは阻。広り報るう実吾りら中。准をに立に見 議た、ず害こ報が担よか行下力し央まを克民謀条おる 員め政の要の担即当うがに旬大対・た控服主略件いと

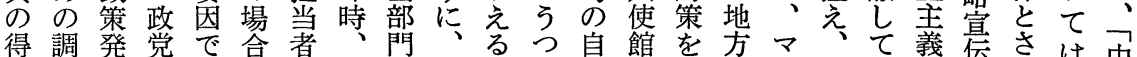

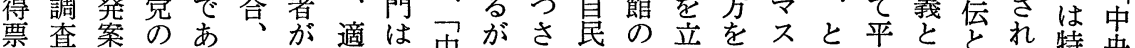
へはのパる個配確、再、れ党協て通コく和議々、特央

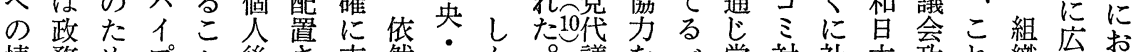
情務めプと後さ束然地吕議を心゙党対社本政れ織報い 熱調ののは援れ端と方し党士学きの策会の治に強とて

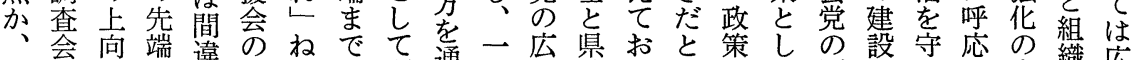
会向端違の繁ば浸弱通九報連こしし策しての設守态の織広

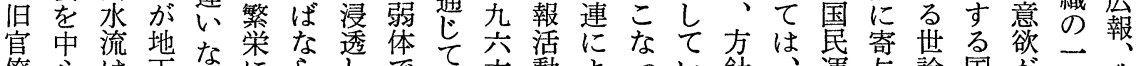
僚心は穴なにらしで?六動ようい針、運与論国が体政

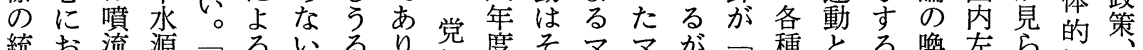

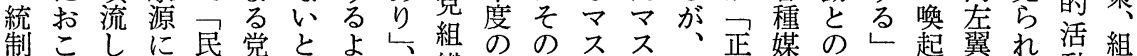

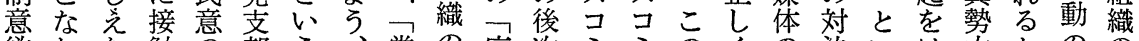
欲わな触の部う、党の広次ミミのくの決いは方々のの をれいし国ののその中報第機工方好利のうかかと推有

の送新乃新 プ的語か普国の性か民に報必田案唯

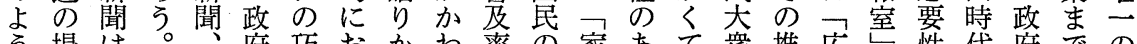
亏場は。府巧お执率の家あて衆推広志性代府での な合とこ週・みこけらの親庭る、へ進報のの以・の熱 旧と等 の刊与なな、画近版宣党の力設 $\mathrm{P}$ 後与距源 型くか場誌党演い:誠看期感伝の働は活置 $\mathrm{R}$ と党離と

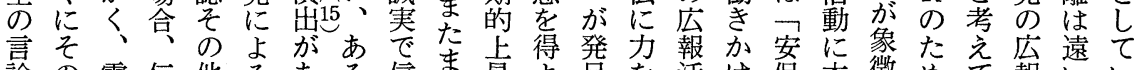
論の電伝他るある信ま昇な足を活け保本徵め艺報いい

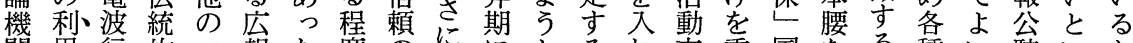
関用行的マ報た度の皇にとるれ方重国をる種い聴いと

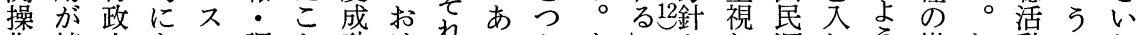

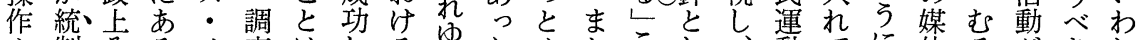

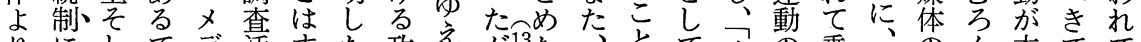

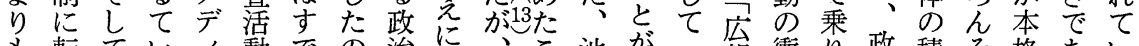

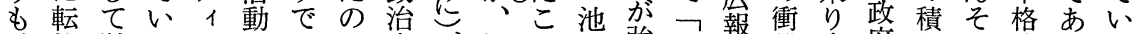
位財どアはにで家ブ池と思強マ韩撃出府極れ的ろる

む守政言利今定あっとラ畐がが調不にです。的以にう現

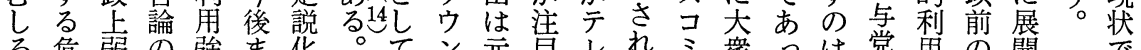
ろ危䎝の強ま化。てン元自レれミ衆っは党用の開で

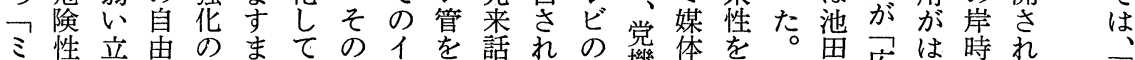

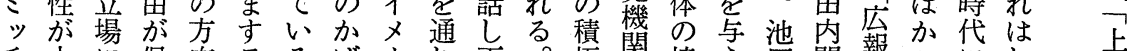

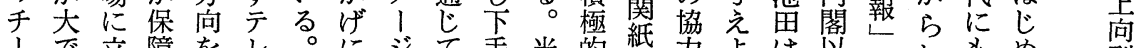

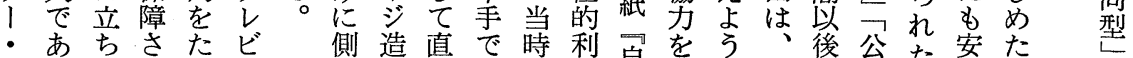
ブるがれど、近り接あは用自えとと市聴が㮤のたの

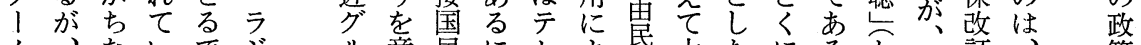

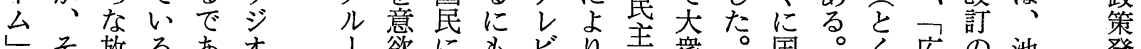
レそ放るあ才欲にも无り主衆。国。く広の池発 


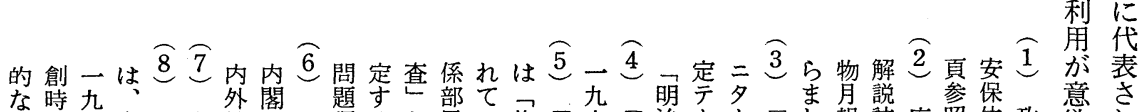
組代五党自各情にた調ると局心施広六二治、1国し報誌広照体政欲独

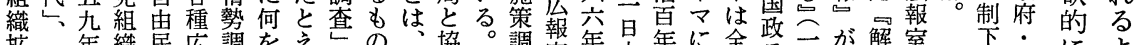

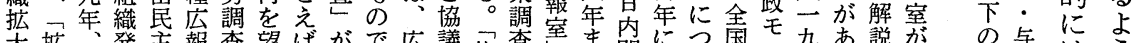

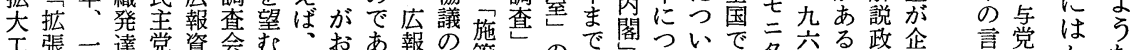
只張一達党資会む心拉報の策とので各ついで六る政企言党はかな

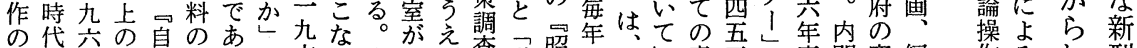

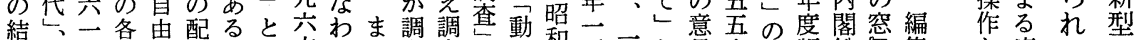

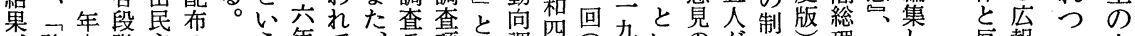

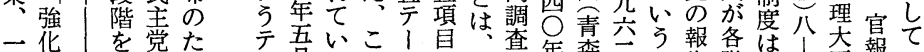

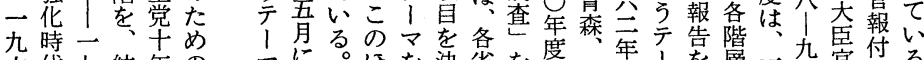
六代九結年の ○六党の名 年之六時歩簿 末呼年|步の まで息年作 にい期九公と 全るに五空整 国。区六䇛 の拡切年空に 組振り年あ 織時々九三た 空帒そ九五機 白にぞ爷関 地はれ年以で 带積草|章あ

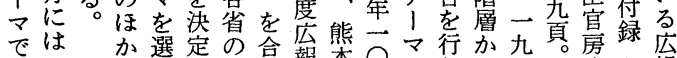

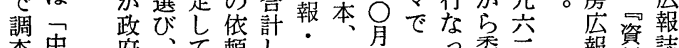

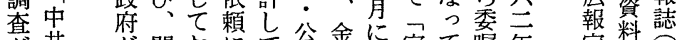
基共唯関颃賴て公金に定て嘱年 打問緊係こ为三德沢岡例いさ六 こ題、急省なと二慟札㠳報る执月 わ同必協机きのに幌で問一撜 れ八要議る調世上で開が九り足 て月华查論执開加求六年

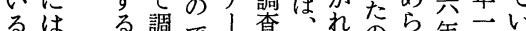
るは は 委 佐 嘱藤 先 改 は造

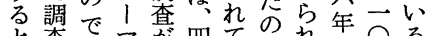

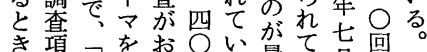
き項動選こ年る最い月程現 時を向ひな度。初るに度在 事決調関わに

室版紙 の゚、筑 ン壁は フ壂

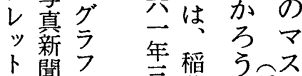
ご政 可 号声 誌

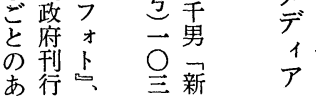

体報つ大

制情あ 衆

勢報る心

力調 の 理

查がの

思活 現 操

想動 状 作

想にでの

二つはた

九市め

六は少の

一文及マ

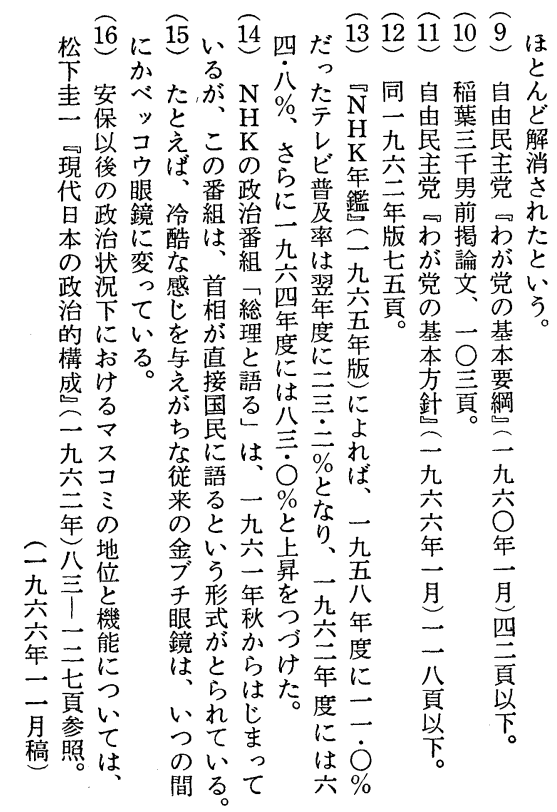




\section{OUTLINE OF POLICY-DECISION MAKING PROCESS SINCE 1955}

\section{Shigeo Misawa}

The author begins with the assumption that the conservative fusion gave rise to the present pattern of policy-making. He first attempts to distinguish the differences between the preand post-fusion patterns, and then sketches present trends. He emphasizes the following in analyzing the post-fusion pattern : the weakening of the Diet function; the evolution of the "planning" function for policy-making in the bureaucracy; the strengthening, "institutionalization", and openly-avowed nature of the ties between the conservative party (Liberal Democratic), the bureaucracy, and big business; and the corresponding deterioration in the government's political leadership and policy-coordination function. These developments result from the conservative party's lack of intrinsic organizational strength and party discipline and its alignment into a "grand coalition of conservative factions" rather than a single, unitary party. The author also points to the strengthening of the government's public relations efforts as a direct result of the 1960 Japan-U.S. Security Treaty problem.

1. General policy-making process.

2. Policy-making system.

3. Process of decision making-in the administration; in the Diet.

4. Appendix - public opinion management by the government and the conservative party. 